\title{
Evaluation of Uncommon Natural Fertilizers Resources for Grapevine Production Grown in Desert Soil
}

\author{
ABDEL WAHAB M. MAHMOUD \\ Plant Physiology Division, Agricultural Botany Department, Faculty of Agriculture, Cairo \\ University, Giza, Egypt.
}

\section{AHMED ALY ELEZABY}

Pomology Department, Faculty of Agriculture, Cairo University, Giza, Egypt.

\author{
HASSAN, A. Z. A
}

Soil- water and Environmental Research Institute, Agricultural Research Center, Giza, Egypt.

Received: April 28, $2018 \quad$ Accepted: May 14, 2018

doi:10.5296/jas.v6i3.13284

URL: https://doi.org/10.5296/jas.v6i3.13284

\begin{abstract}
To economically evaluate production in terms of quality and quantity in newly reclaimed area of desert under drip irrigation system an investigation was conducted for two consecutive seasons in a vineyard to scrutinize the effects of natural zeolite loaded nitrogen, biochar, biofertilizers, nano rice husk with and without nitrogen and organic fertilizer as well as combination of them in comparison to vines fertilized with chemical recommended dose of NPK as control on growth, and chemical components of Superior seedless grapevine cultivar (Vitis vinifera $\mathrm{L}$ ). The outcome data revealed that, mixed between natural zeolite loaded nitrogen, biochar, biofertilizers (Bacillus megaterium and Azotobacter chroococcum), rice husk loaded nitrogen and compost in one mixed treatment led to significant increase in vegetative growth as well as chemical ingredients. Moreover, mixed treatment markedly improved soil chemical and physical properties. Present results confirmed that, mixture of zeolite loaded nitrogen, biochar, biofertilizers, nano rice husk loaded nitrogen and organic fertilizers could supply grape with all essential and beneficial nutrients to achieve high yield with desired market criteria alongside reducing economic costs which reflected from evaluation of investment factor and decline pollution of our ecosystem.
\end{abstract}


Keywords: biochar, biofertilizers, chemical ingredients, grape, investment factor, nano rice husk, zeolite.

\section{Introduction}

Soil chemistry, pedoclimate and environment are working together as symphony called geochemical factor, beside anthropogenic factors, including agronomic performances have profound influences on grape quality and constitutes (Galganoa et al., 2008). Changes or interaction among mentioned factors strongly reflects on the final yield. A huge number of researches have been highlighted the deep and touched influence of nutrients and fertilizing processes and resources (mineral soil addition or foliar, organic compost, manure fertilizers, wastewater etc.) on grape yield quantity and quality. World grape yield production is estimated at more than 76 million tons per year (FAO, 2015). At present time there are more than 19 million acres of cultivated grapevine yards worldwide. Majority of grapevine yards are cultivated in Sandy soils which occupy vast areas in arid and semi-arid regions such as the east and west areas of Egypt. Elements applied to boost inferior fertility of sandy soils were subjected to leaching due to squat water retention of sandy soil (FAO, 2013), which require recurrent irrigation at short intervals. Several applications of naturals and synthesized soil conditioners were derived to correct some physic-bio-chemical properties of sandy soils and their productivity. In this respect, Yasuda et al., (1995) reported that zeolite plays an imperative aspect to alleviate salt harmful effects on plant and gives high productivity to sand soils. In an arid and semi arid environment zeolite has been considered as a good material to improve soil condition. Noori et al., (2007) depicted that, to improve soil quality and augment crop yield its recommended to provide zeolite since cultivation seems to increase yield and avoid the harmful salt when zeolite supply in many crops. Biochar due to its ability to be used in environmental management practices and as a sorbent for some environmental contaminants, including heavy metals has been a widely researched material Reddy et al., (2014a). As a results, continuing research indicated bio-char as a unique landfill cover amendment for supported microbial methane oxidation due to its sorption properties, stability in soil and high internal microporosity, Reddy et al., (2014b). Bio-char has gained more interest due to its different uses such as a soil amendment and carbon sequestration agent for enhance agricultural productivity Shackley and Sohi, (2010). Meanwhile Hassan et al., (2017) illustrated that, convert rice husk mixed aluminium foil (as a houses and restaurants wastes) into nano zeolitic materials (NZ) as novel safety fertilizer, hydrophilic, supplement by potassium, organophillic material (fitting for living beneficial microorganisms represent in two strains of bacteria, Azotobacter chroococeom for nitrogen fixation to balance the deficiency of nitrogen inside zeolite and Bacillus megaterium for phosphorus solubilizing) and environmental friendly to avoid of atmospheric black cloud and its harmful effects.

Therefore, depending on the exploitation concept of low cost natural resources exist in our environment and convert it into fertilizers-like materials for crops production under new reclaimed area of the desert and avoiding chemical pollution, our present research was emerged to make an economic assess on the effects of natural zeolite loaded nitrogen, nano rice husk with or without loaded nitrogen, biochar loaded biofertilizers and their combinations in the presence and absence of organic matter on some hydro-physical 
characteristics of sandy soil as well as on morphological growth, chemical constituents and yield quality of seedless grapevines.

\section{Material and Methods}

At a private vineyard farm (7 years old) cultivated with own-rooted Superior seedless grapevine cultivar (Vitis vinifera $\mathrm{L}$ ) organically managed, representing newly reclaimed area of desert in Wadi El-Notron, Beheira governorate, Longitude $28^{\circ} 54^{\prime}$ E, Latitude $28^{\circ} 20 \mathrm{~N}$ and Altitude $130 \mathrm{~m}$. Egypt, the experiment took place for two successive seasons (2016) 2017). Some physical properties and chemical analysis of the experimental farm soil (Table 1) was carried out as described by Page et al (1982). Vines were spaced 2 meters apart within row and 3 meter between rows, irrigated by drip irrigation system, cane-pruned and trellised by the double $\mathrm{T}$ shape system. The vines were pruned during the second week of January with bud load of 60 buds/vine. Each six vines represent a replicate, each treatment contain three replicates (18 vines) the total uniform vines were 144 represented the whole experiment. All vines were subjected to the normal horticultural practices.

Table (1). Some physical and chemical properties of experimental soil.

\begin{tabular}{|c|c|c|c|}
\hline \multicolumn{2}{|c|}{ Physical properties } & \multicolumn{2}{|l|}{ Chemical properties } \\
\hline \multicolumn{2}{|l|}{ Particle size distribution [\%] } & Electrical conductivity (EC dS/m) & 1.68 \\
\hline Coarse sand $(2000-200 \mu)$ & 80.2 & $\mathrm{pH}(1: 2.5)$ soil : water suspension & 7.68 \\
\hline Fine sand $(200-20 \mu)$ & 12.5 & \multicolumn{2}{|l|}{ Soluble cations (meq/l): } \\
\hline Silt $(20-2 \mu)$ & 4.3 & $\mathrm{Ca}^{2+}$ & 5.20 \\
\hline Clay $(<2 \mu)$ & 3.1 & $\mathrm{Mg}^{2+}$ & 4.18 \\
\hline Bulk density $\left[\mathrm{g} / \mathrm{cm}^{3}\right]$ & 1.52 & $\mathrm{~K}^{+}$ & 2.40 \\
\hline Total porosity [\%] & 52.8 & $\mathrm{Na}^{+}$ & 5.20 \\
\hline \multicolumn{2}{|c|}{ Pore size distribution as $\%$ of total porosity } & \multicolumn{2}{|l|}{ Soluble anions (meq/l): } \\
\hline Macro (drainable) pores $(>28.8 \mu)$ & 82.98 & $\mathrm{CO}_{3}{ }^{2-}$ & $\mathrm{ND} * *$ \\
\hline Micro pores $(<28.8 \mu)$ & 17.02 & $\mathrm{HCO}^{3-}$ & 1.7 \\
\hline Water Holding Capacity (WHC)* & 20.33 & $\mathrm{Cl}^{-}$ & 3.6 \\
\hline Field capacity $(\mathrm{FC})^{*}$ & 8.55 & $\mathrm{SO}_{4}^{2-}$ & 11.50 \\
\hline Wilting percentage $(\mathrm{WP})^{*}$ & 4.10 & Total carbonate $(\%)$ & 0.2 \\
\hline Available moisture (FC-WP)* & 4.45 & \multirow{2}{*}{ Organic matter $(\%)$} & \multirow{2}{*}{0.2} \\
\hline Hydraulic conductivity $[\mathrm{cm} / \mathrm{h}]$ & 6.25 & & \\
\hline
\end{tabular}

$* \%$ on weight basis. $* *$ ND : not detected 


\section{Macrothink}

Chemical fertilizers:

Chemical fertilizers were applied as recommended rates according to the Ministry of Agriculture and Land Reclamation at $80 \mathrm{Kg} \mathrm{N} / \mathrm{fed}$. ammonium nitrate $(33.5 \% \mathrm{~N}) ; 45 \mathrm{Kg}$. $\mathrm{P}_{2} \mathrm{O}_{5} /$ fed. calcium superphoshate $\left(15.5 \% \mathrm{P}_{2} \mathrm{O}_{5}\right)$ and $150 \mathrm{Kg} \cdot \mathrm{K}_{2} \mathrm{O} /$ fed. potassium sulfate $\left(48 \% \mathrm{~K}_{2} \mathrm{O}\right)$. Ammonium nitrate was divided into 3 doses between each one 21 days started on $5^{\text {th }}$ February, while calcium superphoshate and potassium sulfate were added on $15^{\text {th }}$ February during both seasons.

Zeolite loaded nitrogen:

Natural zeolite in the form of granules (Fig. 1) was obtained from Yogyakarta province, Indonesia, were loaded by nitrogen (Table 2) by soaking in $1 \mathrm{M}$ ammonium sulphate solution for 5 days (Junxi Li et.al. 2013) at $25{ }^{\circ} \mathrm{C}$ and aeration condition. The total $\mathrm{N}$ content was analyzed using the Kjeldahl digestion method (Helrich 1990).

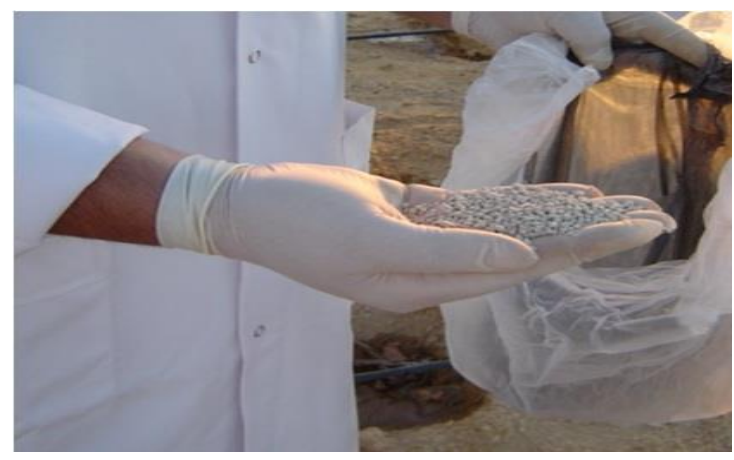

Fig (1): zeolite granules

Table (2). Chemical composition of zeolite after loaded by $\mathrm{N}$

\begin{tabular}{|c|c|c|c|c|c|c|c|c|c|c|c|c|c|}
\hline \multirow{2}{*}{$\begin{array}{c}\text { Chemical } \\
\text { Composition \% }\end{array}$} & $\mathrm{SiO}_{2}$ & $\mathrm{TiO}_{2}$ & $\mathrm{Al}_{2} \mathrm{O}_{3}$ & $\mathrm{Fe}_{2} \mathrm{O}_{3}$ & $\mathrm{FeO}$ & $\mathrm{MnO}$ & $\mathrm{MgO}$ & $\mathrm{CaO}$ & $\mathrm{Na}_{2} \mathrm{O}$ & $\mathrm{K}_{2} \mathrm{O}$ & $\mathrm{SrO}$ & $\mathrm{P}_{2} \mathrm{O}_{3}$ & $\mathrm{~N}$ \\
\hline & 45.50 & 2.81 & 13.30 & 5.40 & 8.31 & 0.51 & 6.30 & 9.52 & 2.83 & 0.87 & 0.22 & 0.67 & 2.70 \\
\hline \multirow{2}{*}{$\begin{array}{c}\text { Trace elements } \\
\text { ppm }\end{array}$} & $\mathrm{Ba}$ & Co & $\mathrm{Cr}$ & $\mathrm{Se}$ & $\mathrm{Cu}$ & $\mathrm{Zn}$ & $\mathrm{Zr}$ & $\mathrm{Nb}$ & $\mathrm{Ni}$ & $\mathrm{Rb}$ & $\mathrm{Y}$ & & \\
\hline & 10 & 1.2 & 35 & 0.8 & 19 & 64 & 257 & 13 & 55 & 15 & 22 & & \\
\hline
\end{tabular}

Organic matter (compost) and zeolite:

Compost (Table 3) at the rate of 5 tons / fed. as well as Zeolite $310 \mathrm{~kg} / \mathrm{fed}$ were added during dormant season on January $15^{\text {th }}$ for both seasons. 


\section{Macrothink}

Journal of Agricultural Studies

ISSN 2166-0379

2018, Vol. 6, No. 3

Table (3). Some chemical characteristics of the applied organic fertilizer

\begin{tabular}{|c|c|c|c|c|c|c|c|c|c|c|c|c|c|c|}
\hline 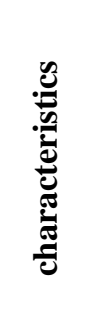 & 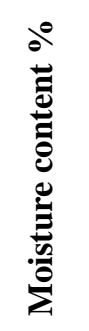 & 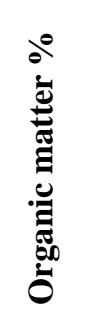 & 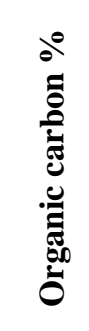 & 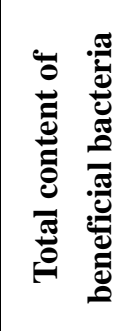 & 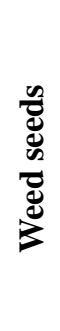 & 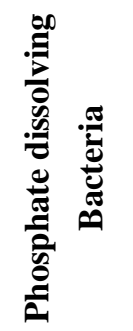 & 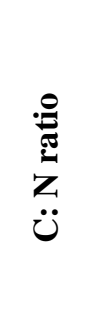 & $\begin{array}{l}0^{\circ} \\
Z\end{array}$ & $\begin{array}{l}\therefore \\
a\end{array}$ & $\begin{array}{l}80 \\
v\end{array}$ & 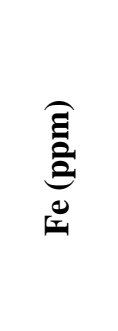 & $\begin{array}{l}\widehat{\Xi} \\
\text { : } \\
\text { ज्ञ }\end{array}$ & 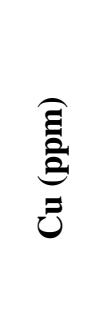 & 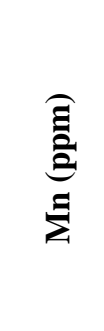 \\
\hline value & 11.7 & 44.3 & 25.4 & $2.5 \times 10^{6}$ & 0 & $2.5 \times 10^{4}$ & 23.1 & 1.80 & 0.59 & 1.30 & 825.21 & 246.37 & 22.64 & 102.41 \\
\hline
\end{tabular}

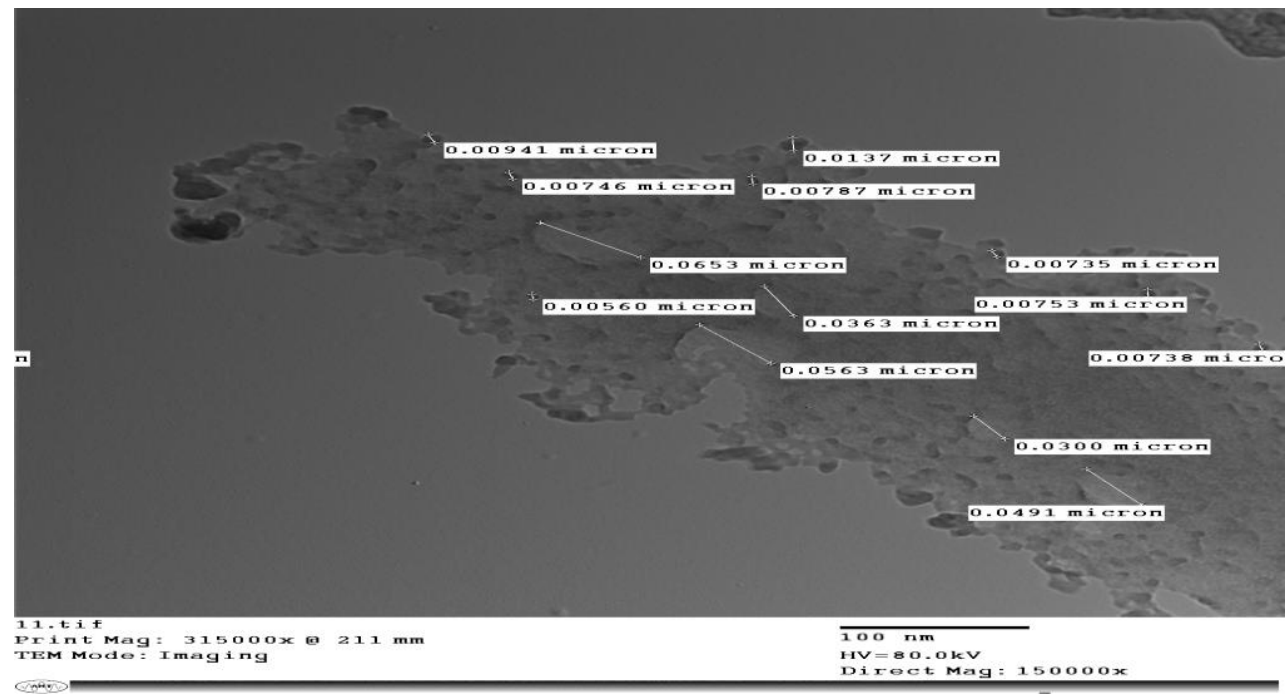

(Fig. 2). Nano rice husk by TEM

Nano-rice husk:-

The material was prepared according to Hassan et.al (2017) subsequently examined by transmission electron microscope (TEM) as visual technique (Fig. 2), then loaded with Nitrogen (Table 4) by soaking it in ammonium sulphate solution (1M) for 7 days (Junxi Li et.al, 2013) at $25 \mathrm{C}^{\mathrm{o}}$ under aeration condition, then applied as foliar (3gram per litter) on $5^{\text {th }}$ March 2016 monthly for 3 months then repeated at the same time and same manner during $3^{\text {th }}$ March 2017.

Table (4). Chemical composition of nano rice-husk loaded nitrogen

\begin{tabular}{|l|c|c|c|c|c|c|c|c|c|c|l|}
\hline Components\% & $\mathrm{SiO}_{2}$ & $\mathrm{Al}_{2} \mathrm{O}_{3}$ & $\mathrm{Fe}_{2} \mathrm{O}_{3}$ & $\begin{array}{c}\mathrm{Mg} \\
\mathrm{O}\end{array}$ & $\begin{array}{c}\mathrm{Ca} \\
\mathrm{O}\end{array}$ & $\mathrm{Na}_{2} \mathrm{O}$ & $\mathrm{K}_{2} \mathrm{O}$ & $\begin{array}{c}\mathrm{P}_{2} \mathrm{O} \\
5\end{array}$ & $\begin{array}{c}\mathrm{Zn} \\
\mathrm{O}\end{array}$ & $\begin{array}{l}\mathrm{N} \\
\text { on } \\
\text { ignition }\end{array}$ \\
\hline Rice husk & 89.1 & 2.0 & 0.08 & 0.24 & 0.42 & 0.20 & 2.11 & 0.76 & 0.05 & 2.4 & 2.64 \\
\hline
\end{tabular}




\section{Macrothink}

\section{Biofertilizers:}

Two bacterial cultures strains containing $1 \times 113^{8} \mathrm{CFU} / \mathrm{ml}$ from Bacillus megaterium and Azotobacter chroococcum were prepared individually in Biofertilizers unit, at the Soils Water and Environ. Res. Inst., Dept. of Microbiology (A. R. C.), Giza, Egypt, Then, they were well mixed together in liquid water at equal portions $(1: 1 \mathrm{v} / \mathrm{v})$.

Biochar preparation:

Biochar (Fig. 3) from rice husk at the rate of 5 tones per fadden was prepared after collected subsequent to harvesting season of rice crop from El-Sharkya province, Egypt, and cut into small parts then put in an oven at $350{ }^{\circ} \mathrm{C}$, for $28 \mathrm{hrs}$. in absence of oxygen with long-term stability as slow pyrolysis technique, then examined by scan electron microscope (SEM) .

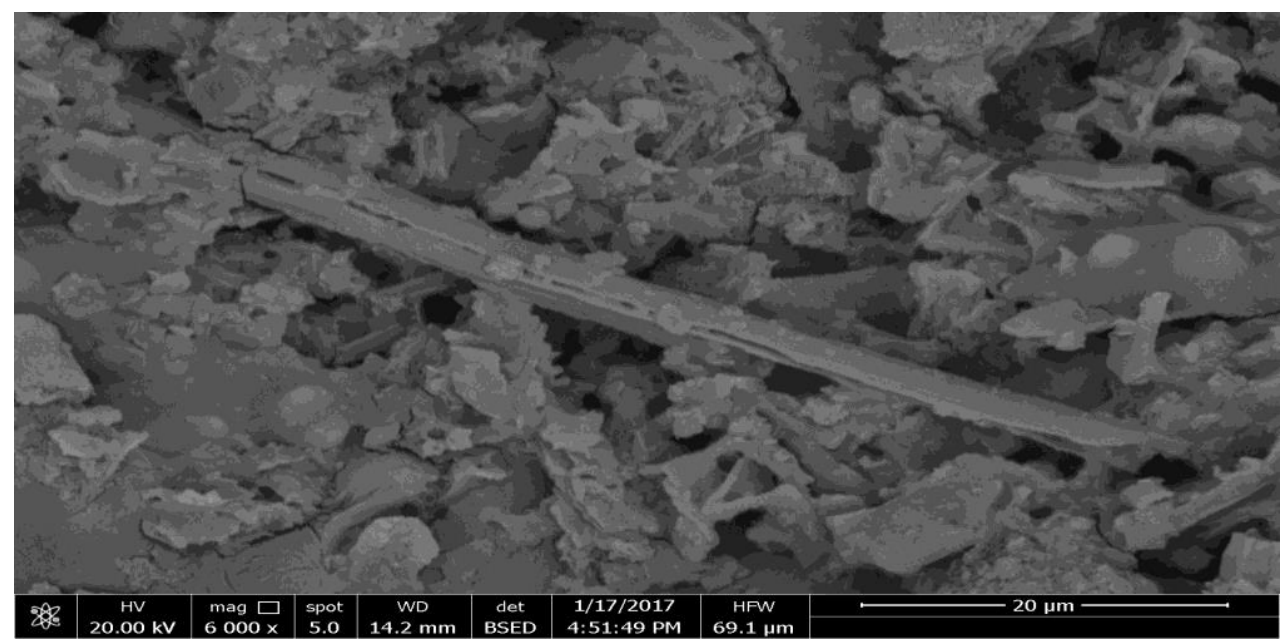

Fig. (3). Biochar as shown using SEM technique

\section{Biochar with Biofertilizers:}

The combined bacteria (Bacillus megaterium and Azotobacter chroococcum) strains were mixed with biochar in 50 litters tank for 48 hours (Fig. 4, a \& b) then applied to plants' rhizosphere on $3^{\text {rd }}$ of February 2016 then repeated at 30, 45 and 60 days from the first inoculation during the first season and repeated with the same manner in the second season starting from $5^{\text {th }}$ of February 2017. 


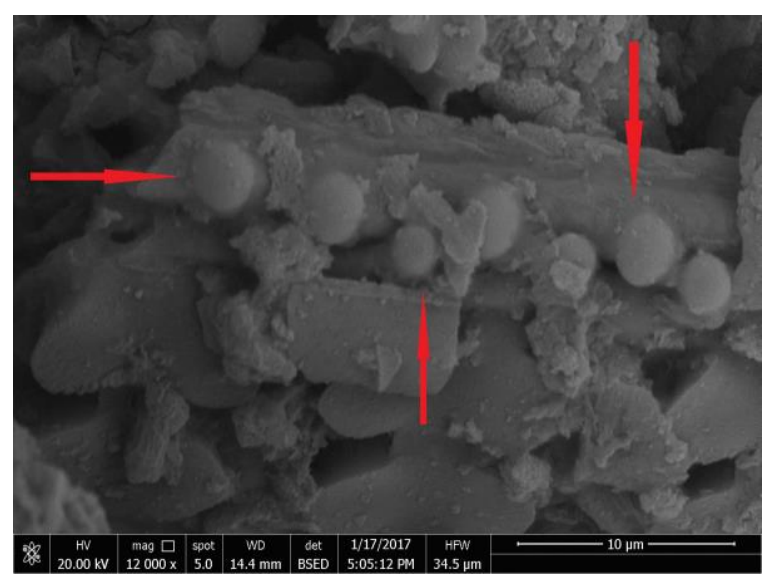

a)

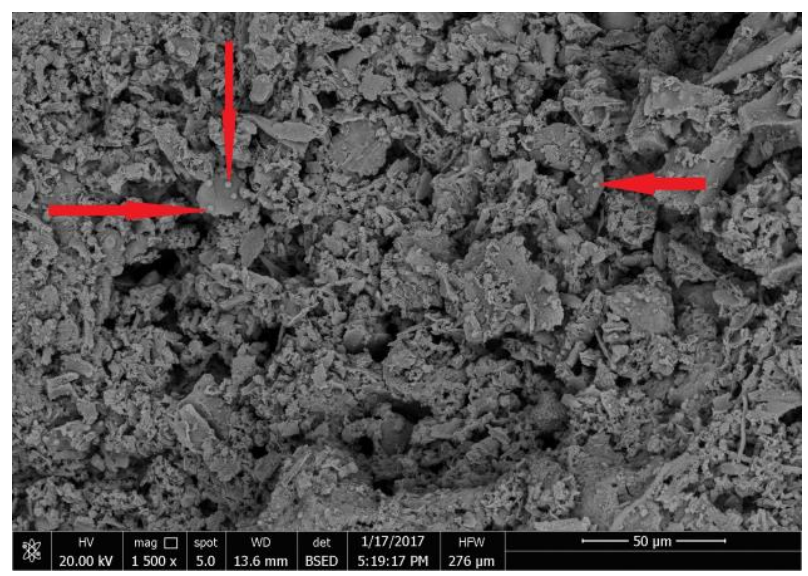

b)

Fig. 4 (a \&b). Biochar inoculated with bacteria as shown using SEM technique

During the two successive seasons the treatments were as follows:

- $\quad$ NPK fertilizers + organic matter (as control)

- Natural zeolite loaded nitrogen + organic matter

- Biochar + biofertilizers + organic matter

- $\quad$ Biochar + Biofertilizers

- Nano rice husk + organic matter

- $\quad$ Nano rice husk

- $\quad$ Rice husk nano loaded nitrogen + organic matter

- $\quad(\mathrm{T} 2+\mathrm{T} 4+\mathrm{T} 7)$ 


\section{Macrothink}

\section{Data recorded}

The following data were recorded:

1. Vegetative growth parameters

- Shoot length $(\mathrm{cm})$

- Shoot diameter $\left(\mathrm{mm}^{2)}\right.$

- Total leaf area/vine $\left(\mathrm{m}^{2}\right)$

- Coefficient of wood ripening

- Shattering (\%)

- Cluster weight (g)

- Berry weight (g)

- Berry size (cm3)

- Yield/vine (Kg)

\section{Chemical Analysis:}

Leaves (blades and petioles) were picked from those opposite to the basal clusters, while clusters collected when soluble solids content (SSC) reached $19 \%$ of control.

Total chlorophylls concentrations:

Total chlorophylls contents (mg/g fresh weight leaves) were measured using the spectrophotometer and calculated according to the equation described by Moran, (1982).

Total carbohydrates concentrations (\%):

The percentage of total carbohydrate in leaves was determined as reported by Helrich, (1990).

Net photosynthesis, stomatal conductance and water use efficiency:

Measurements of net photosynthesis in leaves on an area basis $\left(\mu \mathrm{mol} \mathrm{CO}_{2} \mathrm{~m}^{-2} \mathrm{~s}^{-1}\right)$, leaf stomatal conductance ( $\mathrm{mol} \mathrm{H}_{2} \mathrm{O} \mathrm{m}^{-2} \mathrm{~s}^{-1}$ ), and water use efficiency of five different leaves per treatment was monitored using a LICOR 6400 (Lincoln, Nebraska, USA) infrared gas analyzer (IRGA). Light intensity (Photosynthetically active radiation, PAR) within the sampling chamber was set at $1500 \mu \mathrm{mol} \mathrm{m} \mathrm{m}^{-2}$, using a Li-6400- 02B LED light source (LI-COR). The $\mathrm{CO}_{2}$ flow into the chamber was maintained at a concentration of $400 \mu \mathrm{mol}$ $\mathrm{mol}^{-1}$ using an LI-6400-01 $\mathrm{CO}_{2}$ mixer (LI-COR).

Nitrogen and crude protein concentrations

The total nitrogen content of the dried leaves was determined as described by Helrich, (1990). The nitrogen percentage was multiplied by 6.25 to estimate the crude protein percentages.

Phosphorus concentrations

Phosphorus was determined calorimetrically in leaves according to Jackson (1973). 


\section{Macrothink}

Journal of Agricultural Studies

ISSN 2166-0379

2018, Vol. 6, No. 3

Potassium and sodium concentrations:

Potassium and Sodium concentrations were determined in dried leaves using flame photometer apparatus (CORNING M 410, Germany).

Calcium, magnesium, iron, aluminum, copper, boron, molybdenum, lead, nickel and zinc concentrations:

Were determined using Inductively Coupled Plasma Emission Spectrometer "ICP"

The Agilent 720/730 series US).

Vitamin C:

Vitamin C as ascorbic acid (mg\100g) was determined in leaves according to Helrich, (1990) method.

Determination of organic acids:

Organic acids extraction from berries at harvesting time, were determinate according to Bevilacqua and Califano (1989) using (HPX-87H, $300 \times 7.8 \mathrm{~mm}$, Bio-Rad) 1100 series HPLC G 1322 A, Germany.

Determination of sugars concentrations:

Berries samples were prepared at harvesting time then sugars determinate according to the method described by Melgarejo et al (2000).

Total phenolics

Total phenolic contents of the leaves extracts were determined spectrophotometrically according to the Folin-Ciocalteu colorimetric method Singleton and Rossi, (1965).

Total flavonoids concentrations

Total flavonoids were determined in leaves using the method of Meda et al (2005). HPLC analysis of thiamine

Assays of thiamine in leaves were carried out using a method described by (Rapala-Kozik et al., 2008).

\section{Endogenous phytohormones}

Freeze-dried plant leaves (equivalent $6 \mathrm{~g} \mathrm{FW}$ ) were ground to a fine powder within a mortar and pestle. The powdered material was extracted three times $(1 \times 3 \mathrm{~h} .2 \times 1 \mathrm{~h})$ with methanol $(80 \%$ v/v, $15 \mathrm{ml} . / \mathrm{g} \quad \mathrm{F}$. W. $)$, supplemented with butylated hydroxy toluene (2. (6)-Di-tret-Butyl-P-crosol) as an antioxidant, at $4{ }^{\circ} \mathrm{C}$ in darkness. The extract was centrifuged at $4000 \mathrm{rpm}$. The supernatant was transferred into flasks wrapped with aluminum foil and the residue was twice extracted again. The supernatants were combined and the volume was reduced to $10 \mathrm{ml}$ at $35^{\circ} \mathrm{C}$ under vacuum. The aqueous extract was adjusted to $\mathrm{pH} 8.6$ and extracted three times with an equal volume of pure ethyl acetate. The combined alkaline ethyl acetate extract was dehydrated over anhydrous sodium sulphate then filtered. The filtrate was 
evaporated to dryness under vacuum at $35^{\circ} \mathrm{C}$ and redissolved in $1 \mathrm{ml}$ absolute methanol. The methanol extract was used after methylation according to (Fales et al. 1973) for determination of Gibberellic acid (GA), abscisic acid (ABA) and indole-acetic acid (IAA). The quantification of the endogenous phytohormones was carried out with Ati-Unicum gas-liquid chromatography, 610 Series, equipped with flame ionization detector according to the method described by (Vogel 1975). The fractionation of phytohormones was conducted using a coiled glass column $(1.5 \mathrm{~m} \mathrm{x} 4 \mathrm{~mm}$.) packed with $1 \% \mathrm{OV}-17$. Gases flow rates were $30,30,330 \mathrm{ml} / \mathrm{min}$, for nitrogen, hydrogen and air, respectively. The peaks identification and quantification of phytohormones were performed by using external authentic hormones and a Microsoft program to calculate the concentrations of the identified peaks.

soil chemical and hydro-physical properties

At the end of two seasons, representative soil samples $(0-30 \mathrm{~cm}$ depth $)$ for eight treatments were collected to estimate some soil chemical and hydro-physical properties. Soil salinity, soluble cations and anions were calculated according to Page (1982).Particle size distribution by Dewis and Freitas, (1970).Soil bulk density by Page (1982).Total soil porosity was calculated using the data of bulk density..Soil moisture characteristics were carried out for each treatment over the range from 0 to $15 \mathrm{~atm}$.Using the pressure cooker for the pressure of 0.1 and 0.33 atm., and the pressure membrane apparatus for the pressure $>1$ atm. Pore size distribution and available water were calculated by McIntyre and Loveday,(1974) method.The hydraulic conductivity was measured under constant head according to (Klute, 1965).

Statistical analysis:

The experiment was performed as a Randomized Complete Block Design (RCBD) with eight treatments and three replicates. The data were analyzed using ANOVA at 5\% significance level, the difference between treatments means then analyzed using DMRT (Duncan Multiple Range Test) at $5 \%$.( Duncan, 1955).

Economical evaluation

The yield components were calculated and economic analysis was performed using the following equations proposed by Sarwar et al., (2007); FAO, (2000) and Mubashir et al., (2010).

Gross income $=$ yield $\times$ price

Profitable return $(\mathrm{PR})=$ gross income - total production cost

$\mathrm{PR} \%$ over control $=\mathrm{PR}-$ control treatments

Benefit cost ratio $(\mathrm{BCR})=\mathrm{PR}$ over control $/$ total production cost

Investment factor $(\mathrm{IF})=$ gross income $/$ total production cost

(IF) must equal or more than 3. 


\section{1) Macrothink}

\section{Results and discussion}

The influence of different treatments represented in natural zeolite loaded nitrogen, biochar, biofertilizers, nano rice husk with and without nitrogen and organic matter and combination of them in comparison to chemical recommended dose of NPK plus organic matter as control on vegetative growth, yield, chemical components and economic productivity of superior grape seedless cultivar (Vitis vinifera L) during two consecutive seasons (2016 and 2017) can be enlightened in the following tables and figures:-

\section{a- Soil chemical properties as influenced by the conditioner additives}

Several soil chemical properties were affected by different treatments. The treated soil by different treatments alone or combined with them were less saline than the untreated ones(T1) as shown in (Table 5). Noori et al., (2007) cited that, employing natural zeolite improves soil characters and escalates crop yield, where application of natural zeolite in radish cultivation resulted in magnify yield and also avoid the harmful salt. Hassan et al., (2017) reported that nano rice husk had hydro and organophillic properties that led to maintain water and nutrients in soil Nikolas, (2017) suggested that, organic coating on biochar increases its water and nutrients retention and stimulation of soil fertility.

Soil $\mathrm{pH}$ values were slightly decreased in their values at all treatments against the NPK control treatment (T1).

Table (5). Some chemical properties of the surface layer $(0-30 \mathrm{~cm})$ of Wadi-EL-Natron soil as influenced by different treatments.

\begin{tabular}{|l|c|c|c|c|c|c|c|c|c|}
\hline \multirow{2}{*}{ Treatments } & \multirow{2}{*}{$\mathbf{p H}$} & $\mathbf{E C}$ & \multicolumn{4}{|c|}{ Soluble cations (meq /l) } & \multicolumn{3}{c|}{ Soluble anions (meq /) } \\
\cline { 5 - 12 } & & $\mathbf{d S / m})$ & $\mathbf{C a}^{2+}$ & $\mathbf{M g}^{2+}$ & $\mathbf{K}^{+}$ & $\mathbf{N a}^{+}$ & $\mathbf{H C O}_{\mathbf{3}}{ }^{-}$ & $\mathbf{C l}$ & $\mathbf{S O}_{\mathbf{4}}{ }^{2-}$ \\
\hline T1(NPK-control)+O & 7.97 & 1.70 & 4.15 & 4.25 & 0.60 & 8.00 & 2.81 & 6.56 & 7.63 \\
\hline T2(natural zeolite+ N)+O & 7.91 & 1.68 & 4.10 & 4.19 & 0.48 & 8.03 & 2.30 & 6.37 & 8.13 \\
\hline T3(Biochar+bact)+O & 7.89 & 1.55 & 3.55 & 3.21 & 0.59 & 8.15 & 2.30 & 6.27 & 6.93 \\
\hline T4(Biochar+bact) & 7.80 & 1.53 & 3.18 & 3.33 & 0.54 & 8.25 & 2.73 & 3.68 & 9.89 \\
\hline T5(Rice husk nano)+O & 7.76 & 1.50 & 3.15 & 3.30 & 0.52 & 8.20 & 2.70 & 3.65 & 8.82 \\
\hline T6(Richusk nano+N) & 7.71 & 1.47 & 3.10 & 3.28 & $0.5-0$ & 8.15 & 2.68 & 3.58 & 8.77 \\
\hline T7(Rice husk nano)+O & 7.70 & 1.44 & 3.55 & 3.16 & 0.44 & 8.25 & 2.30 & 6.37 & 6.737 \\
\hline T8(T2+T4+T7) & 7.68 & 1.40 & 3.30 & 2.37 & 0.33 & 8.00 & 2.59 & 3.82 & 7.59 \\
\hline
\end{tabular}




\section{b- Soil hydro physical properties as influenced by different treatments in sandy soil:}

1- Soil texture

Data in Table (6) showed that soil texture at the end of experiment, was still sandy in both treated and untreated soil.

\section{Bulk density and total porosity}

Table (6) revealed that, the appliance of all treatments alone or in combination led to improvement in both soil bulk density and total porosity. The values of bulk density were reduced from $\mathrm{T} 2$ tracked by $\mathrm{T} 3, \mathrm{~T} 4, \mathrm{~T} 5, \mathrm{~T} 6, \mathrm{~T} 7$, and $\mathrm{T} 8$, while the values of total porosity were boosted from T2 to T8, respectively judged against control treatment(T1). Present data can be attributed to the redistribution of soil particles, the increment in bulk soil volume refers to the binding action of all treatments which estimate to enhance soil structure, primarily in aggregates formation .Moreover (natural zeolite, biochar loading biofertilizers, rice husk nano particles, and their combinations has high water-holding capacity and affect the soil physicochemical characteristics, which are essential in controlling the nutrients uptake, their retention and counteracting soil acidity (Hassan et al., 2017).

Table (6). Some hydro-physical properties of the tested soil as affected by different treatments in sandy soil.

\begin{tabular}{|c|c|c|c|c|c|c|c|c|}
\hline \multirow[b]{2}{*}{ Soil Properties } & \multicolumn{8}{|c|}{ Treatments } \\
\hline & 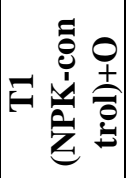 & 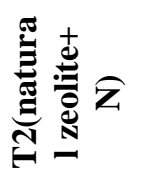 & 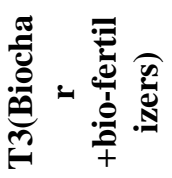 & 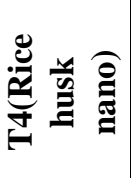 & 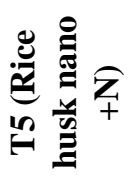 & 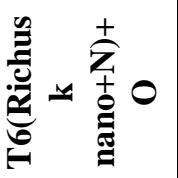 & 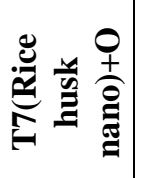 & 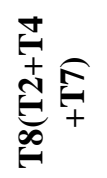 \\
\hline \multicolumn{9}{|c|}{ Particle size distribution $\%$} \\
\hline - Coarse sand (\%) & 65.64 & 66.47 & 64.27 & 67.95 & 68.75 & 66.50 & 67.30 & 63.70 \\
\hline - Fine sand $(\%)$ & 20.23 & 19.38 & 20.64 & 20.05 & 20.25 & 21.45 & 21.70 & 20.30 \\
\hline$-\operatorname{Silt}(\%)$ & 9.24 & 9.14 & 9.29 & 7.20 & 8.50 & 8.00 & 7.51 & 8.57 \\
\hline - Clay $(\%)$ & 4.89 & 5.01 & 5.80 & 4.80 & 2.50 & 4.05 & 3.49 & 7.43 \\
\hline Texture class & Sandy & Sandy & Sandy & Sandy & Sandy & Sandy & Sandy & Sandy \\
\hline Bulk density $\left(\mathrm{g} / \mathrm{cm}^{3}\right)$ & 1.68 & 1.65 & 1.60 & 1.58 & 1.56 & 1.53 & 1.53 & 1.52 \\
\hline Total porosity $(\%)$ & 37.37 & 37.99 & 38.28 & 38.38 & 38.59 & 39.28 & 39.30 & 41.78 \\
\hline $\begin{array}{l}\text { Water holding } \\
\text { capacity* }(\%)\end{array}$ & 21.94 & 22.46 & 23.5 & 24.1 & 24.35 & 24.85 & 24.78 & 26.13 \\
\hline Field capacity $(\%)^{*}$ & 6.37 & 9.97 & 10.04 & 10.60 & 10.95 & 11.00 & 11.03 & 12.98 \\
\hline $\begin{array}{l}\text { Wilting } \\
\text { percentage }(\%) *\end{array}$ & 1.22 & 3.03 & 3.21 & 3.26 & 3.01 & 1.96 & 1.90 & 1.85 \\
\hline Available water*(\%) & 5.15 & 6.94 & 6.83 & 7.34 & 7.94 & 9.04 & 9.13 & 11.13 \\
\hline $\begin{array}{l}\text { Hydraulic } \\
\text { conductivity }(\mathrm{Cm} / \mathrm{h})\end{array}$ & 6.23 & 6.13 & 5.86 & 5.58 & 5.14 & 4.25 & 4.23 & 4.05 \\
\hline
\end{tabular}

*On weight basis

The influence of all treatments individually or in combinations of them on soil moisture retentions, i.e. total water holding capacity (WHC), field capacity (FC) and wilting 
percentage. The (WP) as well as the available water of sandy soil were shown in (Table 6). displayed that the elevate in soil (WHC) reached maximum value with (T8) tracked by T7, T6, T5, T4, T3, T2, as compared to control treatment(T1). Moreover, the percent water held by treated soil was greater than that held by NPK control treatment at both FC and WP. The augment in moisture retained at field capacity attained to maximum value for T8 followed by T7, T6, T5, T4, T3 and T2. Moreover increasing available water was reached over two fold for T8 against $\mathrm{T} 1$ followed by T7, T6, T5, T4, T3 and T2 after treating sandy soil. These may be rendered to the increase in soil moisture retention for natural zeolite, nano rice husk, and biochar. This increase in soil moisture retention parameters were agreement with results reported by Hassan et.al., (2017) and Nikolas, (2017) who suggested that biochar coating organic matter can retain water and nutrients in soil.

Pore size distribution

Pore size distribution for sandy soil of Wadi El-Natron were changed by different treatments and expressed in Fig.1. It was clear that, micro pores $(<28.8 \mathrm{p})$ notably those responsible for the accessible moisture i.e. water holding pores (W.H.P, 28.8-0.19p) were augmented on the opposite of the macro ones which correspond to the total drainable pores (T.D.P, >28.8p). Meanwhile, fine capillary pores (F.C.P) which hold soil moisture at the wilting percentage, are slightly enlarged. Data might point to the redistribution of solid particles after supplying soil by different conditioners treatments. In this case, soil aggregates can be established, hence the water holding pores increased and consequently available moisture in the treated soils, this results were concord with Hassan et al., (2017) who pointed that, nano zeolitic materials (syntheses, nano zeolite derived from rice husk) were hydrophillic. Moreover, Bio-char advances soil quality by its effects on key soil processes. Several advantages of bio-char resultant from its extremely porous structure and combined high surface area, with its high porosity generally soil water holding capacity was increased. Furthermore improving soil water retention and in category minimize nutrient loss throughout leaching via the small pore spaces with positively charged surfaces Jeffery et al., (2011). Zeolites can also perform as water mediators, in which they will absorb up to $55 \%$ of their weight in water and gradually release it under plant require (Jean and Dupont,1983). 


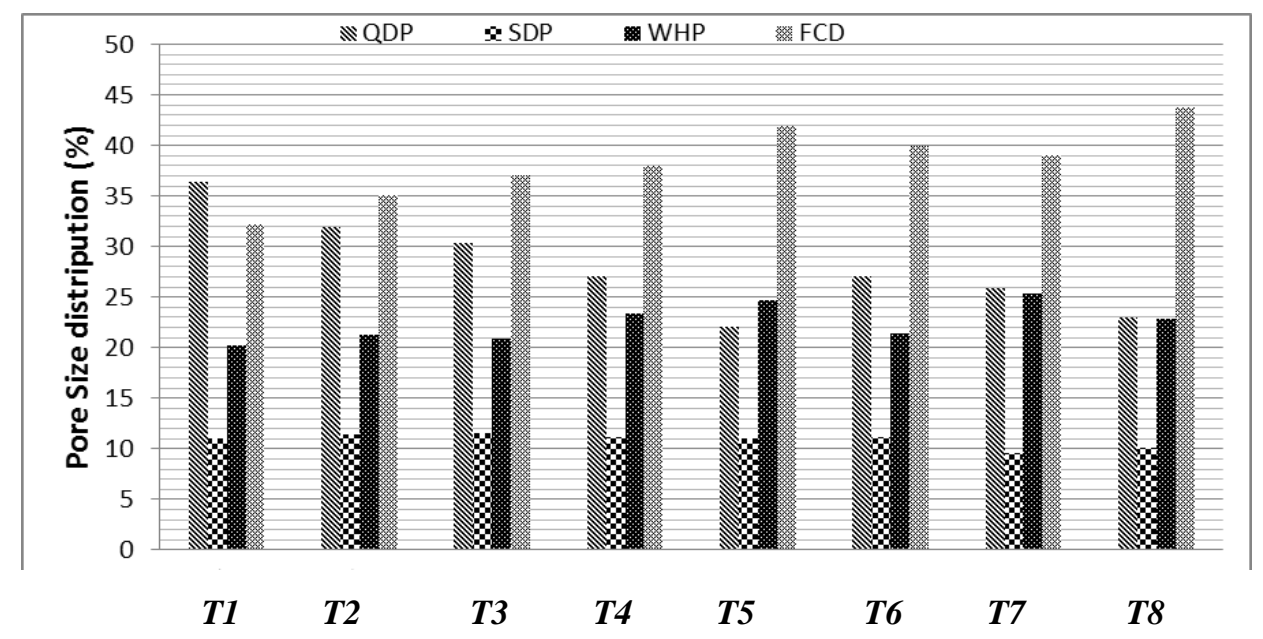

Fig. (5). Pore size distribution as affected by natural zeolite loaded nitrogen, biochar, biofertilizers, nano rice husk with and without nitrogen, organic matter and combination of them in comparison to chemical recommended dose of NPK

Data in Table (6) illustrated that, the saturated hydraulic conductivity values measured for the surface layer, were sharply decreased with different treatments alone or combined. The supreme reduce in "K" values was recorded at T8 and tracked by T7,T6, T5, T4, T3 and T2 evaluator against the NPK control treatment T1. This low hydraulic conductivity referred to very small pore (nano pores ) for zeolitic materials which destruction and close the residual pores and agglomerate the particles so, prevent the intake of water inside the soil .This results were consonance with Hassan and Mahmoud, (2015) and Nikolas, (2017) who illustrated that stretched bio-char particle form rising inter-pores space after soil wetting led to close the voids, macro and micro pores between soil particles, and coating sandy particles so increase water retention and nutrients.

Growth parameters:

The gained outcomes of present investigation on plant growth characters disclosed that, combination treatment (T8) significantly increased almost all favorable growth traits compared to control treatment (T1) as represented in (Table 7), where mixed between natural zeolite loaded nitrogen, biochar, biofertilizers (Bacillus megaterium and Azotobacter chroococcum), rice husk loaded nitrogen and compost in one treatment (T8) recorded remarkable increment in both seasons for leaf area (42 and 46\%), shoot diameter (54 and $46 \%$ ), shoot length (14 and 15\%) and coefficient of wood ripening (39 and 40\%) respectively over control plants and all other combination treatments. 


\section{Macrothink}

Journal of Agricultural Studies

ISSN 2166-0379

2018, Vol. 6, No. 3

Table (7). Effect of different treatments on leaf area, shoot diameter, shoots length and coefficient wood of Superior grapevine (Vitis vinifera L) during two consecutive seasons $(\mathrm{S} 1=2016$ and $\mathrm{S} 2=2017)$.

\begin{tabular}{|c|c|c|c|c|c|c|c|c|}
\hline \multirow[t]{2}{*}{ Treatments } & \multicolumn{2}{|c|}{$\begin{array}{c}\text { Total leaf } \\
\text { area/vine }\left(\mathbf{m}^{2}\right)\end{array}$} & \multicolumn{2}{|c|}{$\begin{array}{c}\text { Shoot diameter } \\
\left(\mathrm{mm}^{2)}\right.\end{array}$} & \multicolumn{2}{|c|}{$\begin{array}{c}\text { Shoot length } \\
\text { (cm) }\end{array}$} & \multicolumn{2}{|c|}{$\begin{array}{c}\text { Coefficient of wood } \\
\text { ripening }\end{array}$} \\
\hline & S1 & $\mathbf{S 2}$ & S1 & $\mathbf{S 2}$ & S1 & $\mathbf{S 2}$ & S1 & S2 \\
\hline T1 (NPK-control)+O & $14.7^{\mathrm{c}}$ & $15.3^{\mathrm{c}}$ & $5.3^{\mathrm{c}}$ & $5.9^{\mathrm{b}}$ & $78.5^{\mathrm{d}}$ & $81.7^{\mathrm{b}}$ & $0.61^{\mathrm{c}}$ & $0.63^{\mathrm{c}}$ \\
\hline $\begin{array}{l}\mathrm{T} 2 \text { (naturalzeolite }+ \\
\mathrm{N})+\mathrm{O}\end{array}$ & $15.5^{\mathrm{b}}$ & $18.4^{\mathrm{b}}$ & $6.1^{\mathrm{b}}$ & $6.3^{\mathrm{b}}$ & $85.4^{\mathrm{b}}$ & $90.8^{\mathrm{a}}$ & $0.68^{\mathrm{b}}$ & $0.70^{\mathrm{b}}$ \\
\hline $\mathrm{T} 3$ (Biochar+bact) $+\mathrm{O}$ & $13.2^{\mathrm{d}}$ & $14.6^{\mathrm{d}}$ & $5.1^{\mathrm{c}}$ & $5.8^{\mathrm{b}}$ & $78.8^{\mathrm{d}}$ & $82.6^{\mathrm{b}}$ & $0.58^{\mathrm{c}}$ & $0.62^{\mathrm{d}}$ \\
\hline T4(Biochar+bact) & $10.5^{\mathrm{f}}$ & $12.4^{\mathrm{f}}$ & $4.0^{\mathrm{d}}$ & $5.2^{\mathrm{c}}$ & $75.2^{\mathrm{e}}$ & $78.4 \mathrm{c}$ & $0.56^{\mathrm{d}}$ & $0.59^{\mathrm{d}}$ \\
\hline T5(Rice husk nano)+O & $12.7^{\mathrm{e}}$ & $13.5^{\mathrm{e}}$ & $4.2^{\mathrm{d}}$ & $5.0^{\mathrm{c}}$ & $73.5^{\mathrm{e}}$ & $77.8^{\mathrm{c}}$ & $0.56^{\mathrm{d}}$ & $0.60^{\mathrm{d}}$ \\
\hline T6(Rice husk nano) & $8.7^{\mathrm{g}}$ & $10.6^{\mathrm{g}}$ & $3.5^{\mathrm{e}}$ & $4.8^{\mathrm{c}}$ & $69.1^{\mathrm{f}}$ & $74.3^{\mathrm{d}}$ & $0.54^{\mathrm{d}}$ & $0.57^{\mathrm{e}}$ \\
\hline $\begin{array}{l}\text { T7(Richusk } \\
\text { nano+N)+O }\end{array}$ & $14.6^{\mathrm{c}}$ & $17.8^{\mathrm{b}}$ & $5.8^{\mathrm{b}}$ & $6.5^{\mathrm{b}}$ & $80.7^{\mathrm{c}}$ & $84.3^{b}$ & $0.60^{\mathrm{c}}$ & $0.65^{\mathrm{c}}$ \\
\hline $\mathrm{T} 8(\mathrm{~T} 2+\mathrm{T} 4+\mathrm{T} 7)$ & $20.8^{\mathrm{a}}$ & $22.3^{\mathrm{a}}$ & $8.2^{\mathrm{a}}$ & $8.6^{\mathrm{a}}$ & $89.6^{\mathrm{a}}$ & $94.2^{\mathrm{a}}$ & $0.85^{\mathrm{a}}$ & $0.88^{\mathrm{a}}$ \\
\hline
\end{tabular}

Means with the same letter in a column are not significantly different by DMRT 5\%

Moreover, application of treatment $\mathrm{T} 8$ had the same trend results significantly superior to data of control plants in both seasons for cluster weight (8.2 and 8.1\%), berry weight (12 and $10 \%)$, berry size (7.5 and $10.5 \%)$ and yield (22.5 and 13\%) respectively (Table 8$)$.

Meanwhile it was lucid that, application of T2 treatment symbolized in natural zeolite loaded nitrogen in the presence of organic matter and $\mathrm{T} 7$ composed of rice husk loaded nitrogen mixed with compost were had insightful effect in increased mentioned growth parameters in Tables (1 and 2) as compared to control plants, although some of these increments were insignificant.

Away from previous data, it was distinguished that, both treatments T4 and T6 as well application produced minimum growth characters (Table 7 and 8) compared to control plants and other combinations during both seasons as after effect. 
Table (8). Effect of different treatments on yield, cluster and berry weight, berry size and shattering of Superior grapevine (Vitis vinifera L) during two consecutive seasons (S1=2016 and $\mathrm{S} 2=2017$ ).

\begin{tabular}{|l|c|c|c|c|c|c|c|c|c|c|}
\hline \multirow{2}{*}{ Treatments } & \multicolumn{2}{|c|}{$\begin{array}{r}\text { Yield/vine } \\
(\mathbf{K g})\end{array}$} & \multicolumn{2}{c|}{$\begin{array}{c}\text { Cluster weight } \\
(\mathbf{g})\end{array}$} & \multicolumn{2}{c|}{$\begin{array}{c}\text { Berry weight } \\
(\mathbf{g})\end{array}$} & \multicolumn{2}{c|}{$\begin{array}{c}\text { Berry size } \\
(\mathbf{c m 3})\end{array}$} & \multicolumn{2}{c|}{$\begin{array}{c}\text { Shattering } \\
(\%)\end{array}$} \\
\cline { 2 - 11 } & $\mathbf{S 1}$ & $\mathbf{S 2}$ & $\mathbf{S 1}$ & $\mathbf{S 2}$ & $\mathbf{S 1}$ & $\mathbf{S 2}$ & $\mathbf{S 1}$ & $\mathbf{S 2}$ & $\mathbf{S 1}$ & $\mathbf{S 2}$ \\
\hline T1 (NPK-control)+O & $7.16 \mathrm{c}$ & $8.21 \mathrm{c}$ & $395.7 \mathrm{c}$ & $413.4 \mathrm{c}$ & $2.17 \mathrm{~d}$ & $2.26 \mathrm{c}$ & $2.19 \mathrm{~b}$ & $2.28 \mathrm{c}$ & $22.61 \mathrm{a}$ & $22.88 \mathrm{~b}$ \\
\hline T2(natural zeolite+N)+O & $7.49 \mathrm{~b}$ & $8.72 \mathrm{~b}$ & $418.5 \mathrm{~b}$ & $425 \mathrm{~b}$ & $2.35 \mathrm{~b}$ & $2.43 \mathrm{a}$ & $2.30 \mathrm{a}$ & $2.39 \mathrm{~b}$ & $21.31 \mathrm{~b}$ & $20.40 \mathrm{c}$ \\
\hline T3(Biochar+bact)+O & $7.31 \mathrm{~b}$ & $8.48 \mathrm{c}$ & $401 \mathrm{c}$ & $415.7 \mathrm{c}$ & $2.23 \mathrm{c}$ & $2.28 \mathrm{c}$ & $2.21 \mathrm{~b}$ & $2.27 \mathrm{c}$ & $22.36 \mathrm{a}$ & $22.39 \mathrm{~b}$ \\
\hline T4(Biochar+bact) & $5.22 \mathrm{~d}$ & $6.17 \mathrm{~d}$ & $350.4 \mathrm{e}$ & $388.5 \mathrm{e}$ & $1.87 \mathrm{e}$ & $1.96 \mathrm{e}$ & $1.84 \mathrm{c}$ & $1.93 \mathrm{e}$ & $23.45 \mathrm{a}$ & $22.31 \mathrm{~b}$ \\
\hline T5(Rice husk nano)+O & $7.03 \mathrm{c}$ & $8.16 \mathrm{c}$ & $374.3 \mathrm{~d}$ & $403.5 \mathrm{~d}$ & $2.14 \mathrm{~d}$ & $2.20 \mathrm{~d}$ & $1.89 \mathrm{c}$ & $2.13 \mathrm{~d}$ & $23.12 \mathrm{a}$ & $24.11 \mathrm{a}$ \\
\hline T6(Rice husk nano) & $3.85 \mathrm{e}$ & $4.30 \mathrm{e}$ & $298.7 \mathrm{f}$ & $322.7 \mathrm{f}$ & $1.80 \mathrm{e}$ & $1.89 \mathrm{e}$ & $1.70 \mathrm{~d}$ & $1.88 \mathrm{e}$ & $24.01 \mathrm{a}$ & $23 \mathrm{a}$ \\
\hline T7(Richusk nano+N)+O & $7.45 \mathrm{~b}$ & $8.68 \mathrm{~b}$ & $414.2 \mathrm{~b}$ & $422.6 \mathrm{~b}$ & $2.31 \mathrm{~b}$ & $2.38 \mathrm{~b}$ & $2.29 \mathrm{a}$ & $2.38 \mathrm{~b}$ & $21.50 \mathrm{~b}$ & $20.48 \mathrm{c}$ \\
\hline T8(T2+T4+T7) & $8.77 \mathrm{a}$ & $9.25 \mathrm{a}$ & $428.5 \mathrm{a}$ & $447 \mathrm{a}$ & $2.43 \mathrm{a}$ & $2.49 \mathrm{a}$ & $2.35 \mathrm{a}$ & $2.52 \mathrm{a}$ & $19.64 \mathrm{c}$ & $18.57 \mathrm{~d}$ \\
\hline
\end{tabular}

Means with the same letter in a column are not significantly different by DMRT 5\%

Present outcome data provided a reasonable biological mechanism for how the combination of natural zeolite loaded nitrogen, biochar, biofertilizers, nano-rice husk loaded nitrogen and organic matter together led to pivotal consequence as increase growth parameters over control, that increases spring from their advantageous effects represented in, providing plants with a source of $\mathrm{N}$ and undoubtedly supplied the growing plants with required macro and micronutrients, hormones like substances from biofertilizers, simultaneously with available and retention of water by improving dynamic soil-water characteristics, i.e. decreasing the downward water movement through infiltration and its upward movement via evaporation from zeolite, biochar, nano-rice husk and compost. Hence improved soil physical and chemical properties reflected on boosted growth traits including yield quality; this has an immense effect in desert reclamation processes.

Supportive evidences for present data were reported by Hassan et al., (2006) who found that rosemary plants received compost mixture with bio-fertilizers recorded considerable increments in growth characteristics. Moreover, Li et al., (2013) on kale (Brassica alboglabra) indicated that, application of ammonium and potassium-loaded zeolite resulted in an increase in the total harvest weight over control plants. Furthermore Mahmoud et al., (2017) worked on caraway plants, showed that, application of humic substances, natural nano-zeolite-loaded nitrogen and biofertilizers mixture gave eminent results on either plant under investigation and environment that presents with higher growth characteristics and chemical composition in comparison with results derived from chemical fertilizers NPK as control. As well Abdurahman, (2017) concluded that, incorporated biochar, farmyard manure, and mineral nitrogen fertilizer into soil increased availability of plant nutrients concentration 
in the soil and plant uptake.

B. Chemical analysis

Nutrients content

It was discernible from data in Tables ( 9 and 10) that, elevation in macro and micronutrients were significant as a result of combination treatment T8 appliance during both seasons, that increments as represented in macro elements $\mathrm{N}, \mathrm{P}, \mathrm{K}, \mathrm{Ca}$ and $\mathrm{Mg}$ were 16 and $25 \%$ for nitrogen, 52 and $46 \%$ for phosphorus, 24 and $22 \%$ for potassium, 190 and $133 \%$ for calcium and 43 and $68 \%$ for magnesium, respectively judged against control treatment $\mathrm{T} 1$.

Table (9). Effect of different treatments on macro elements of Superior grapevine (Vitis vinifera $\mathrm{L}$ ) leaves during two consecutive seasons ( $1=2016$ and $\mathrm{S} 2=2017$ ).

\begin{tabular}{|l|c|c|c|c|c|c|c|c|c|c|}
\hline \multirow{2}{*}{ Treatments } & \multicolumn{2}{|c|}{ N\% } & \multicolumn{2}{c|}{ P\% } & \multicolumn{2}{c|}{ K\% } & \multicolumn{2}{c|}{ Ca\% } & \multicolumn{2}{c|}{ Mg\% } \\
\cline { 2 - 11 } & S1 & S2 & S1 & S2 & S1 & S2 & S1 & S2 & S1 & S2 \\
\hline T1(NPK-control)+O & $2.06 \mathrm{~b}$ & $2.13 \mathrm{~b}$ & $0.29 \mathrm{c}$ & $0.32 \mathrm{c}$ & $1.53 \mathrm{c}$ & $1.66 \mathrm{~b}$ & $0.94 \mathrm{~d}$ & $1.28 \mathrm{c}$ & $0.79 \mathrm{~d}$ & $0.90 \mathrm{c}$ \\
\hline T2(natural zeolite+N)+O & $2.15 \mathrm{~b}$ & $2.25 \mathrm{a}$ & $0.33 \mathrm{~b}$ & $0.36 \mathrm{~b}$ & $1.90 \mathrm{a}$ & $2.05 \mathrm{a}$ & $2.41 \mathrm{~b}$ & $2.65 \mathrm{~b}$ & $1.09 \mathrm{a}$ & $1.18 \mathrm{~b}$ \\
\hline T3(Biochar+bact)+O & $1.85 \mathrm{c}$ & $1.96 \mathrm{c}$ & $0.27 \mathrm{c}$ & $0.30 \mathrm{c}$ & $1.54 \mathrm{c}$ & $1.63 \mathrm{c}$ & $1.03 \mathrm{c}$ & $1.11 \mathrm{~d}$ & $0.85 \mathrm{c}$ & $0.91 \mathrm{c}$ \\
\hline T4(Biochar+bact) & $1.42 \mathrm{e}$ & $1.55 \mathrm{e}$ & $0.23 \mathrm{~d}$ & $0.25 \mathrm{~d}$ & $1.52 \mathrm{c}$ & $1.60 \mathrm{c}$ & $0.75 \mathrm{~d}$ & $0.96 \mathrm{~d}$ & $0.77 \mathrm{~d}$ & $0.85 \mathrm{~d}$ \\
\hline T5(Rice husk nano)+O & $1.51 \mathrm{~d}$ & $1.62 \mathrm{~d}$ & $0.25 \mathrm{c}$ & $0.26 \mathrm{~d}$ & $1.59 \mathrm{c}$ & $1.68 \mathrm{~b}$ & $1.15 \mathrm{c}$ & $1.23 \mathrm{c}$ & $0.88 \mathrm{c}$ & $0.95 \mathrm{c}$ \\
\hline T6(Rice husk nano) & $1.26 \mathrm{f}$ & $1.32 \mathrm{f}$ & $0.21 \mathrm{~d}$ & $0.22 \mathrm{e}$ & $1.65 \mathrm{~b}$ & $1.69 \mathrm{~b}$ & $1.01 \mathrm{c}$ & $1.20 \mathrm{c}$ & $0.80 \mathrm{~d}$ & $0.87 \mathrm{~d}$ \\
\hline T7(Ric husk nano+N)+O & $2.08 \mathrm{~b}$ & $2.14 \mathrm{~b}$ & $0.30 \mathrm{~b}$ & $0.34 \mathrm{~b}$ & $1.70 \mathrm{~b}$ & $1.75 \mathrm{~b}$ & $2.39 \mathrm{~b}$ & $2.70 \mathrm{~b}$ & $0.98 \mathrm{~b}$ & $1.20 \mathrm{~b}$ \\
\hline T8(T2+T4+T7) & $2.38 \mathrm{a}$ & $2.66 \mathrm{a}$ & $0.44 \mathrm{a}$ & $0.47 \mathrm{a}$ & $1.89 \mathrm{a}$ & $2.03 \mathrm{a}$ & $2.73 \mathrm{a}$ & $2.98 \mathrm{a}$ & $1.13 \mathrm{a}$ & $1.51 \mathrm{a}$ \\
\hline
\end{tabular}

Means with the same letter in a column are not significantly different by DMRT 5\%

Going with microelements, similar results were obtained since application of T8 treatment gave significant profound effect particularly on Fe 24 and 31\%, 20 and 21\% for Mn, 82 and $58 \%$ for $\mathrm{Zn}, 21$ and $61 \%$ for $\mathrm{Cu}$ and 50 and $169 \%$ for $\mathrm{B}$ respectively for both seasons in comparison to control treatment (T1). 


\section{Macrothink}

Journal of Agricultural Studies

ISSN 2166-0379

2018, Vol. 6, No. 3

Table (10). Effect of different treatments on microelements of Superior grapevine (Vitis vinifera $\mathrm{L}$ ) leaves during two consecutive seasons (S1=2016 and S2=2017).

\begin{tabular}{|l|c|c|c|c|c|c|c|c|c|c|}
\hline \multirow{2}{*}{ Treatments } & \multicolumn{2}{|c|}{ B ppm } & \multicolumn{2}{c|}{ Cu ppm } & \multicolumn{2}{c|}{ Fe ppm } & \multicolumn{2}{c|}{ Mn ppm } & \multicolumn{2}{c|}{ Zn ppm } \\
\cline { 2 - 11 } & S1 & S2 & S1 & S2 & S1 & S2 & S1 & S2 & S1 & S2 \\
\hline T1 (NPK-control)+O & $40.39 \mathrm{c}$ & $29.58 \mathrm{e}$ & $6.21 \mathrm{~b}$ & $5.20 \mathrm{c}$ & $200.8 \mathrm{c}$ & $219.5 \mathrm{c}$ & $113.6 \mathrm{c}$ & $118.9 \mathrm{~d}$ & $39.25 \mathrm{c}$ & $50.72 \mathrm{c}$ \\
\hline T2 (natural zeolite+N)+O & $51.88 \mathrm{~b}$ & $62.33 \mathrm{~b}$ & $6.64 \mathrm{~b}$ & $7.11 \mathrm{~b}$ & $240.5 \mathrm{~b}$ & $255.3 \mathrm{~b}$ & $122.4 \mathrm{~b}$ & $128.5 \mathrm{c}$ & $63.42 \mathrm{~b}$ & $70.58 \mathrm{~b}$ \\
\hline T3(Biochar+bact)+O & $38.72 \mathrm{c}$ & $45.79 \mathrm{c}$ & $5.28 \mathrm{c}$ & $5.17 \mathrm{c}$ & $189.5 \mathrm{~d}$ & $217.2 \mathrm{c}$ & $109.3 \mathrm{c}$ & $115.7 \mathrm{~d}$ & $33.89 \mathrm{~d}$ & $40.71 \mathrm{~d}$ \\
\hline T4(Biochar+bact) & $33.41 \mathrm{~d}$ & $40.11 \mathrm{~d}$ & $4.37 \mathrm{~d}$ & $4.51 \mathrm{~d}$ & $180.7 \mathrm{~d}$ & $200.3 \mathrm{~d}$ & $97.7 \mathrm{e}$ & $105.3 \mathrm{f}$ & $29.64 \mathrm{~d}$ & $35.11 \mathrm{~d}$ \\
\hline T5(Rice husk nano)+O & $31.52 \mathrm{~d}$ & $39.81 \mathrm{~d}$ & $5.50 \mathrm{c}$ & $5.93 \mathrm{c}$ & $205.7 \mathrm{c}$ & $221.5 \mathrm{c}$ & $102 \mathrm{~d}$ & $112.8 \mathrm{e}$ & $41.31 \mathrm{c}$ & $49.08 \mathrm{c}$ \\
\hline T6(Rice husk nano) & $29.74 \mathrm{~d}$ & $35.84 \mathrm{e}$ & $4.68 \mathrm{~d}$ & $5.31 \mathrm{c}$ & $198.6 \mathrm{c}$ & $219 \mathrm{c}$ & $100.5 \mathrm{~d}$ & $107.5 \mathrm{f}$ & $30.18 \mathrm{~d}$ & $36.21 \mathrm{~d}$ \\
\hline T7(Ric husk nano+N)+O & $53.31 \mathrm{~b}$ & $64.27 \mathrm{~b}$ & $6.35 \mathrm{~b}$ & $7.25 \mathrm{~b}$ & $245.7 \mathrm{a}$ & $253.4 \mathrm{~b}$ & $119.6 \mathrm{~b}$ & $135.8 \mathrm{~b}$ & $60.82 \mathrm{~b}$ & $70.03 \mathrm{~b}$ \\
\hline T8(T2+T4+T7) & $60,75 \mathrm{a}$ & $79.64 \mathrm{a}$ & $7.51 \mathrm{a}$ & $8.40 \mathrm{a}$ & $248.9 \mathrm{a}$ & $287.6 \mathrm{a}$ & $136.7 \mathrm{a}$ & $144.2 \mathrm{a}$ & $71.38 \mathrm{a}$ & $80.04 \mathrm{a}$ \\
\hline
\end{tabular}

Means with the same letter in a column are not significantly different by DMRT 5\%

In the interim it was outstanding that, other elements such as Mo, Ni and Al Table (11) also recorded significant enhances accompanied with T8 treatment application with exception of $\mathrm{Na}$ content which donate insignificant results contrasted to control treatment T1. Contrary to previous data, $\mathrm{Pb}$ concentration recorded significant increment with control treatment $\mathrm{T} 1$ over T8treatment and all other treatments during both seasons. Furthermore, as revealed in growth parameters both treatments T2 and T7 as well have the same way where, their application resulted in significant augmentation with most macro and micronutrients compared to control treatment T1 during both seasons. 
Table (11). Effect of different treatments on Molybdenum, sodium, nickel, aluminum and lead of Superior grapevine (Vitis vinifera $\mathrm{L}$ ) leaves during two consecutive seasons $(\mathrm{S} 1=2016$ and $\mathrm{S} 2=2017$ ).

\begin{tabular}{|c|c|c|c|c|c|c|c|c|c|c|}
\hline \multirow{2}{*}{ Treatments } & \multicolumn{2}{|c|}{ Mo ppm } & \multicolumn{2}{|c|}{ Na ppm } & \multicolumn{2}{|c|}{ Ni ppm } & \multicolumn{2}{|c|}{ Al ppm } & \multicolumn{2}{|c|}{ Pb ppm } \\
\hline & S1 & S2 & S1 & S2 & S1 & $\mathbf{S 2}$ & S1 & S2 & S1 & S2 \\
\hline T1 (NPK-control)+O & $0.105 b$ & $0.112 b$ & $24.7 \mathrm{a}$ & $28.5 \mathrm{a}$ & $1.29 \mathrm{c}$ & $1.37 \mathrm{c}$ & $5.98 \mathrm{c}$ & $6.32 \mathrm{c}$ & $0.83 \mathrm{a}$ & $1.05 \mathrm{a}$ \\
\hline $\mathrm{T} 2($ natural zeolite $+\mathrm{N})+\mathrm{O}$ & $0.118 \mathrm{a}$ & $0.327 \mathrm{a}$ & $22.1 \mathrm{a}$ & $26.8 \mathrm{a}$ & $2.51 \mathrm{a}$ & $2.58 \mathrm{a}$ & $10.68 \mathrm{a}$ & $11.47 \mathrm{a}$ & $0.66 \mathrm{c}$ & $0.81 b$ \\
\hline $\mathrm{T} 3$ (Biochar+bact)+O & $0.078 \mathrm{c}$ & $0.096 \mathrm{c}$ & $16.7 \mathrm{~b}$ & $19.1 \mathrm{~b}$ & $1.64 \mathrm{c}$ & $1.69 \mathrm{c}$ & $6.61 \mathrm{c}$ & $7.20 \mathrm{~b}$ & $0.56 \mathrm{~d}$ & $0.63 \mathrm{~d}$ \\
\hline T4(Biochar+bact) & $0.074 \mathrm{c}$ & $0.061 \mathrm{~d}$ & $16.3 \mathrm{~b}$ & $18.3 \mathrm{~b}$ & $1.33 \mathrm{c}$ & $1.54 \mathrm{c}$ & $5.55 \mathrm{c}$ & $5.81 \mathrm{c}$ & $0.55 \mathrm{~d}$ & $0.60 \mathrm{~d}$ \\
\hline T5(Rice husk nano)+O & $0.102 \mathrm{~b}$ & $0.110 \mathrm{~b}$ & $22.4 \mathrm{a}$ & $25.7 \mathrm{a}$ & $2.44 \mathrm{a}$ & $2.48 \mathrm{a}$ & $8.42 \mathrm{~b}$ & $8.78 \mathrm{~b}$ & $0.60 \mathrm{~d}$ & $0.65 \mathrm{~d}$ \\
\hline T6(Rice husk nano) & $0.098 \mathrm{~b}$ & $0.108 \mathrm{~b}$ & $20.5 \mathrm{a}$ & $22 \mathrm{~b}$ & $1.68 \mathrm{c}$ & $1.70 \mathrm{c}$ & $7.69 \mathrm{~b}$ & $8.80 \mathrm{~b}$ & $0.54 \mathrm{~d}$ & $0.58 \mathrm{e}$ \\
\hline $\mathrm{T} 7($ Ric husk nano+N)+O & $0.120 \mathrm{a}$ & $0.298 \mathrm{a}$ & $17.9 \mathrm{~b}$ & $20.4 \mathrm{~b}$ & $2.47 \mathrm{a}$ & $2.53 \mathrm{a}$ & $10.03 \mathrm{a}$ & $10.26 \mathrm{a}$ & $0.67 \mathrm{c}$ & $0.72 \mathrm{c}$ \\
\hline $\mathrm{T} 8(\mathrm{~T} 2+\mathrm{T} 4+\mathrm{T} 7)$ & $0.131 \mathrm{a}$ & $0.341 \mathrm{a}$ & $23.3 \mathrm{a}$ & $27.5 \mathrm{a}$ & $2.54 \mathrm{a}$ & $2.61 \mathrm{a}$ & $11.51 \mathrm{a}$ & $12.26 \mathrm{a}$ & $0.72 b$ & $0.80 \mathrm{~b}$ \\
\hline
\end{tabular}

Means with the same letter in a column are not significantly different by DMRT 5\%

On the far side, T4 and T6 treatments generally gave the lowest amounts of macro and micro nutrients content, some of those diminishing were significant while others were insignificant, meanwhile $\mathrm{T} 6$ recorded significant increases with Al element content over control T1 during both seasons 28 and $39 \%$ respectively and significant increase $7.5 \%$ in Ca compared to control $\mathrm{T} 1$ for the first season.

Many studies have shown that the power of compost as fertilizer due to its content of stabilized organic matter and due to the amount of nutritive elements contained therein Bevacqua and Mellano, (1993).beside the imperative role of natural zeolite (clinoptilolite) containing macro and micronutrients, and its channels grant large surface areas which chemical reactions can take place through making fertilizers more effectual by keeping away from leeching and grasping valuable nutrients such as ammonium nitrate, potassium, magnesium and calcium as well as trace elements for slow release as needed Pirela (1984) and Kallo et al., (1986).

Side by side with biochar and its physicochemical characteristics which consider a reason for alterations in soil nutrients and carbon accessibility, plus offered physical protection to microorganisms from predators and desiccation; this may increase the beneficial microbial diversity within the soil Lehman et al., (2015). Working together with available nitrogen by both loading and fixing bacteria represented in biofertilizers resulted in elevation of macro and micronutrients. Similar results were found by Soliman and Mahmoud, (2013) on Adansonia digitata L. declared that, natural zeolite, organic fertilizer (compost) and combination of them led to significant increase in macro and microelements. Also Robertson et al., (2012) stated that, depending on biochar derived type is characterized by a high content 
of volatile matter that contains easily decomposable substrates, which can support plant growth and nutrients availability. Additionally Huseyin et al., (2007) worked on apple indicated that biofertilizers resulted in significant increases in all nutrients content as affected by bacterial applications compared with the control.

Total chlorophyll, total carbohydrates, total phenolics, flavonoids, ascorbic acid and thiamine

Data represented in Table ( 12 ) indicated that, appliance of T8 treatment in both growing seasons induced significant escalation in total chlorophyll as it presented 25 and 23\%, 20 and $23.5 \%$ for total carbohydrates, 27 and $25.5 \%$ for total phenolics, 30.50 and $43 \%$ for flavonoids, 12 and $11 \%$ for ascorbic acid and 1.5 and $1.8 \%$ for thiamine respectively in comparison with control T1 and all other treatments exception of T7 treatment which gave significant increase in thiamine content 1.5 and $2 \%$ respectively over T1 treatment and insignificant increase compared to T8.

Table (12). Effect of different treatments on chlorophyll, carbohydrate, phenolics, flavonoids, ascorbic acid and thiamine of Superior grapevine (Vitis vinifera L) leaves during two consecutive seasons (S1=2016 and S2=2017).

\begin{tabular}{|c|c|c|c|c|c|c|c|c|c|c|c|c|}
\hline \multirow[t]{2}{*}{ Treatments } & \multicolumn{2}{|c|}{$\begin{array}{l}\text { Total chlorophyll } \\
\text { (mg-gF.W) }\end{array}$} & \multicolumn{2}{|c|}{$\begin{array}{c}\text { Total } \\
\text { carbohydrate } \\
\text { s }(\%)\end{array}$} & \multicolumn{2}{|c|}{$\begin{array}{c}\text { Total } \\
\text { phenolics } \\
\text { GAE/100g } \\
\text { DM }\end{array}$} & \multicolumn{2}{|c|}{$\begin{array}{c}\text { Flavonoids } \\
\text { GAE/100g } \\
\text { DM }\end{array}$} & \multicolumn{2}{|c|}{$\begin{array}{c}\text { Ascorbic acid } \\
\mathrm{mg} / 100 \mathrm{~g}\end{array}$} & \multicolumn{2}{|c|}{$\begin{array}{l}\text { Thiamine } \\
\mu \mathrm{g} / 100 \mathrm{~g}\end{array}$} \\
\hline & S1 & $\mathbf{S 2}$ & S1 & $\mathbf{S 2}$ & S1 & $\mathbf{S 2}$ & S1 & $\mathbf{S 2}$ & S1 & S2 & S1 & $\mathbf{S 2}$ \\
\hline $\mathrm{T} 1(\mathrm{NPK}$-control)+O & $31.6 \mathrm{~d}$ & $33.8 \mathrm{~d}$ & $25.1 \mathrm{c}$ & $26.3 \mathrm{~d}$ & $3.54 \mathrm{c}$ & $4.13 \mathrm{c}$ & $2.59 \mathrm{c}$ & $3.34 \mathrm{~d}$ & $10.15 b$ & $10.89 \mathrm{c}$ & $1374.2 \mathrm{c}$ & $1389.3 b$ \\
\hline $\begin{array}{l}\mathrm{T} 2(\text { natural } \\
\text { zeolite }+\mathrm{N})+\mathrm{O}\end{array}$ & $36.2 b$ & $37.5 b$ & $27.4 \mathrm{~b}$ & $28.1 b$ & $3.74 b$ & $4.66 \mathrm{~b}$ & $3.28 \mathrm{a}$ & $4.42 b$ & $11.10 \mathrm{a}$ & $11.42 b$ & $1381 b$ & $1394.8 b$ \\
\hline $\mathrm{T} 3($ Biochar+bact $)+\mathrm{O}$ & $32.7 \mathrm{~d}$ & $33.7 \mathrm{~d}$ & $24.3 \mathrm{~d}$ & $25.8 \mathrm{~d}$ & $3.18 \mathrm{~d}$ & $3.51 \mathrm{~d}$ & $3.19 \mathrm{~b}$ & $3.52 \mathrm{c}$ & $9.14 \mathrm{c}$ & $9.75 \mathrm{~d}$ & $1344 d$ & $1350.2 \mathrm{c}$ \\
\hline T4(Biochar+bact) & $29.4 d$ & $31.2 \mathrm{~d}$ & $23.5 \mathrm{~d}$ & $24.4 \mathrm{e}$ & $3.17 \mathrm{~d}$ & $3.44 \mathrm{e}$ & $3.15 b$ & $3.23 \mathrm{e}$ & $9.12 \mathrm{c}$ & $9.69 \mathrm{~d}$ & $1335 \mathrm{e}$ & $1341 \mathrm{c}$ \\
\hline $\begin{array}{l}\text { T5(Rice husk } \\
\text { nano)+O }\end{array}$ & $31.3 \mathrm{~d}$ & $33.5 \mathrm{~d}$ & $24.1 \mathrm{~d}$ & $25.3 \mathrm{~d}$ & $3.11 \mathrm{e}$ & $3.53 \mathrm{~d}$ & $2.57 \mathrm{c}$ & $3.08 \mathrm{f}$ & $9.08 \mathrm{c}$ & $9.68 \mathrm{~d}$ & $1298.7 f$ & $1322.6 \mathrm{~d}$ \\
\hline T6(Rice husk nano) & $28.1 \mathrm{e}$ & $30.6 \mathrm{~d}$ & $22.2 \mathrm{e}$ & $23.7 \mathrm{e}$ & $3.16 \mathrm{~d}$ & $3.46 \mathrm{e}$ & $2.50 \mathrm{~d}$ & $2.94 \mathrm{~g}$ & $8.72 \mathrm{~d}$ & $9.11 \mathrm{e}$ & $1270.3 \mathrm{~g}$ & $1312.8 \mathrm{~d}$ \\
\hline $\begin{array}{l}\text { T7( Ric husk } \\
\text { nano+N)+O }\end{array}$ & $34.3 \mathrm{c}$ & $35.5 \mathrm{c}$ & $26.7 b$ & $27.1 \mathrm{c}$ & $3.69 b$ & $4.63 b$ & $3.17 \mathrm{~b}$ & $3.55 \mathrm{c}$ & $10.39 \mathrm{~b}$ & $10.91 \mathrm{c}$ & $1395 \mathrm{a}$ & $1418 \mathrm{a}$ \\
\hline $\mathrm{T} 8(\mathrm{~T} 2+\mathrm{T} 4+\mathrm{T} 7)$ & $39.5 \mathrm{a}$ & $41.7 \mathrm{a}$ & $30.2 \mathrm{a}$ & $32.5 \mathrm{a}$ & $4.51 \mathrm{a}$ & $5.18 \mathrm{a}$ & $3.38 \mathrm{a}$ & $4.79 \mathrm{a}$ & $11.36 \mathrm{a}$ & $12.07 \mathrm{a}$ & $1392.7 \mathrm{a}$ & $1415.4 \mathrm{a}$ \\
\hline
\end{tabular}

Means with the same letter in a column are not significantly different by DMRT 5\% 


\section{Ml Macrothink}

Journal of Agricultural Studies

ISSN 2166-0379

2018, Vol. 6, No. 3

Pertaining to both treatments (T2) and (T7) which recorded raises in previous chemical ingredients, some of those augmentations were significant and others were insignificant compared to control (T1)

The elevated amount in total chlorophyll maybe due to beneficial effects of combination between natural zeolite loaded nitrogen, biochar, biofertilizers, nano rice husk and organic matter on plant pigments since increasing the activity of biochar, compost and biofertilizers to liberate additional nutrients from the unavailable reserves as correcting iron and zinc deficiency in sandy soils which lead to efficiency of photosynthesis process, while the positive role of zeolite, rice husk and compost might be referred to its components of available essential nutrients besides their role in increasing root surface per unit of soil volume as well as the high capacity of the plants building metabolites, which in turn contribute much to the increase of nutrient uptake Mahmoud, (2012). The increase in total carbohydrates could explained on the basis of increase photosynthesis process as after effect of raise in chlorophyll content in leaves White et al., (2016). Meanwhile earlier investigations cleared that; high concentrations of phenolics could be vindicated by the task of organic fertilisers which encourage the acetate shikimate pathway, hence increasing production of flavonoids and phenolics Sousa et al., (2008). fertilisation type had serious effect on the phyto-nutritional aspect of crops. Chemical fertilisers are postulated to reduce the antioxidant content (total phenolics, flavonoids, ascorbic acid and thiamine) while organic fertilizers were certified to improve the antioxidant content in plants (Dumas et al., 2003).

In line with present results were obtained by Soliman and Mahmoud (2013) on Adansonia digitata L, Mahmoud et al (2017) on caraway plant and Chan and Xu (2009) who detected outstanding augment in organic carbon and organic matter within the soil following the incorporation of biochar.

Organic acids, sugars, T.S.S, acidity and crude proteins concentrations

It was lucid from data presented in Table (13) that, combined treatment T8 application significantly resulted in maximum organic acids concentration and sugars (glucose and fructose) as well against either control treatment $\mathrm{T} 1$ or approximately other treatments during both growing seasons since it gave 12 and $11.5 \%$ for citric acid, 16 and $22 \%$ for tartaric acid, 50 and $23 \%$ for malic acid, 10 and $8 \%$ for fructose and 7 and $8 \%$ for glucose respectively.

With reference to $\mathrm{T} 2$ and $\mathrm{T} 7$ treatments, it was notable that, $\mathrm{T} 2$ recorded significant increases in all previous chemical ingredients (organic acids and sugars) compared with control T1 during two growing seasons. Almost same trend was obtained with T7 which donate increases over control $\mathrm{T} 1$ albeit that increases were insignificant only with citric and tartaric acids. 
Table (13). Effect of different treatments on organic acids and sugars of Superior grapevine

(Vitis vinifera L) fruits during two consecutive seasons (S1=2016 and S2=2017).

\begin{tabular}{|c|c|c|c|c|c|c|c|c|c|c|c|c|}
\hline \multirow{3}{*}{ Treatments } & \multicolumn{8}{|c|}{ Organic acids } & \multicolumn{4}{|c|}{ Sugars } \\
\hline & \multicolumn{2}{|c|}{$\begin{array}{c}\text { Citric acid } \\
\text { mg/L }\end{array}$} & \multicolumn{2}{|c|}{$\begin{array}{c}\text { Tartaric } \\
\text { Acid } \\
\text { mg/L }\end{array}$} & \multicolumn{2}{|c|}{$\begin{array}{c}\text { Malic Acid } \\
\text { mg/L }\end{array}$} & \multicolumn{2}{|c|}{$\begin{array}{c}\text { Total acidity } \\
\text { g/L }\end{array}$} & \multicolumn{2}{|c|}{$\begin{array}{l}\text { Fructose } \\
\text { g/100 ml }\end{array}$} & \multicolumn{2}{|c|}{$\begin{array}{l}\text { Glucose } \\
\text { g/100 ml }\end{array}$} \\
\hline & S1 & $\mathbf{S 2}$ & S1 & $\mathbf{S 2}$ & S1 & $\mathbf{S 2}$ & S1 & $\mathbf{S 2}$ & S1 & $\mathbf{S 2}$ & S1 & $\mathbf{S 2}$ \\
\hline $\mathrm{T} 1$ (NPK-control)+O & $56.61 \mathrm{~b}$ & $60.79 \mathrm{~b}$ & $5510 \mathrm{c}$ & $5820 \mathrm{c}$ & $2270 \mathrm{c}$ & $3000 \mathrm{~d}$ & $7.836 \mathrm{c}$ & $8.880 \mathrm{~d}$ & $11.535 \mathrm{c}$ & $11.916 \mathrm{c}$ & $12.609 \mathrm{c}$ & $12.975 \mathrm{c}$ \\
\hline $\begin{array}{l}\mathrm{T} 2 \text { (natural } \\
\text { zeolite }+\mathrm{N} \text { )+O }\end{array}$ & $60.55 \mathrm{a}$ & $64.33 \mathrm{a}$ & $6290 \mathrm{~b}$ & $6620 \mathrm{~b}$ & $3320 b$ & $3510 \mathrm{c}$ & $9.670 \mathrm{a}$ & $10.194 b$ & $12.467 \mathrm{~b}$ & $12.685 b$ & $13.109 b$ & $13.695 b$ \\
\hline $\mathrm{T} 3($ Biochar+bact $)+\mathrm{O}$ & $62.11 \mathrm{a}$ & $65.08 \mathrm{a}$ & $6280 b$ & $6640 b$ & $3380 \mathrm{a}$ & $3620 b$ & $9.722 \mathrm{a}$ & $10.325 \mathrm{a}$ & $11.504 \mathrm{c}$ & $11.931 \mathrm{c}$ & $12.582 \mathrm{c}$ & $12.849 \mathrm{c}$ \\
\hline T4(Biochar+bact) & $59.31 \mathrm{a}$ & $60.13 b$ & $6077 b$ & $6489 b$ & $3291 b$ & $3547 \mathrm{c}$ & $9.427 \mathrm{a}$ & $10.096 \mathrm{~b}$ & $11.473 \mathrm{c}$ & $11.755 \mathrm{c}$ & $12.366 \mathrm{~d}$ & $12.671 \mathrm{c}$ \\
\hline $\begin{array}{l}\text { T5(Rice husk } \\
\text { nano)+O }\end{array}$ & $55.28 \mathrm{~b}$ & $58.21 \mathrm{~b}$ & $5480 \mathrm{c}$ & $5790 \mathrm{c}$ & $2250 \mathrm{c}$ & $2970 \mathrm{e}$ & $7.785 \mathrm{c}$ & $8.818 \mathrm{~d}$ & $11.481 \mathrm{c}$ & $11.869 \mathrm{c}$ & $12.537 \mathrm{c}$ & $12.933 \mathrm{c}$ \\
\hline T6(Rice husk nano) & $51.78 \mathrm{c}$ & $55.86 \mathrm{~b}$ & $5290 \mathrm{c}$ & $5587 \mathrm{c}$ & $2046 d$ & $2881 \mathrm{e}$ & $7.387 \mathrm{c}$ & $8.523 \mathrm{e}$ & $11.320 \mathrm{~d}$ & $11.571 \mathrm{~d}$ & $12.283 \mathrm{~d}$ & $12.489 \mathrm{c}$ \\
\hline $\begin{array}{l}\text { T7(Ric husk } \\
\text { nano+N)+O }\end{array}$ & $56.92 \mathrm{~b}$ & $61.57 \mathrm{~b}$ & $5520 \mathrm{c}$ & $5840 \mathrm{c}$ & $3400 \mathrm{a}$ & $3650 \mathrm{~b}$ & $8.976 b$ & $9.551 \mathrm{c}$ & $12.288 b$ & $12.574 \mathrm{~b}$ & $13.215 b$ & $13.641 b$ \\
\hline T8(T2+T4+T7) & $63.47 \mathrm{a}$ & 67.81a & $6420 \mathrm{a}$ & $7150 \mathrm{a}$ & $3420 a$ & $3700 \mathrm{a}$ & $9.903 \mathrm{a}$ & $10.917 \mathrm{a}$ & $12.685 \mathrm{a}$ & $12.889 a$ & $13.509 \mathrm{a}$ & $14.047 \mathrm{a}$ \\
\hline
\end{tabular}

Means with the same letter in a column are not significantly different by DMRT 5\%

Organic acids considered as water soluble substances exist in the cytoplasm of many fruit and vegetable at different quantities, together with the sugars, they donate the taste of fruit and vegetables (Cemeroglu et al., 2004). In grapes, tartaric acid and malic acids consist of the $90 \%$ of total organic acids (Agaoglu, 2002), meanwhile the chemical content of grape is subjective by different factors such as maturity, variety, growing region, agricultural practices and time of the year (Lamikanra et al., 1995). Hence the increment in mentioned chemical constituents as a result of mixture treatment (T8) application may essential elements that may play an important role in plant metabolism, notably the most significant function would appear to involve in improving carbohydrate metabolism, efficiency of photosynthesis process and some plants use organic acids to manage nutrient deficiencies, metal tolerance and plant-microbe interactions working at the root-soil inter-phase (Tisdale and Nelson, 1975). 
Table (14). Effect of different treatments on T.S.S, acidity in fruits and crude protein in leaves of Superior grapevine (Vitis vinifera L) during two consecutive seasons (S1=2016 and S2=2017).

\begin{tabular}{|c|c|c|c|c|c|c|c|c|}
\hline \multirow{2}{*}{ Treatments } & \multicolumn{2}{|c|}{ T.S.S.(\%) } & \multicolumn{2}{c|}{ Acidity (\%) } & \multicolumn{2}{c|}{ T.S.S./Acidity } & \multicolumn{2}{c|}{ Crude protein \% } \\
\cline { 2 - 9 } & S1 & S2 & S1 & S2 & S1 & S2 & S1 & S2 \\
\hline T1 (NPK-control)+O & $16.30 \mathrm{c}$ & $16.35 \mathrm{c}$ & $0.78^{\mathrm{c}}$ & $0.88^{\mathrm{c}}$ & $20.88 \mathrm{a}$ & $18.57 \mathrm{a}$ & $13 \mathrm{~b}$ & $13.31 \mathrm{c}$ \\
\hline T2(natural zeolite+ N)+O & $16.57 \mathrm{~b}$ & $16.64 \mathrm{~b}$ & $0.96^{\mathrm{a}}$ & $1.01^{\mathrm{a}}$ & $17.26 \mathrm{~b}$ & $16.47 \mathrm{~b}$ & $13.43 \mathrm{~b}$ & $14 \mathrm{~b}$ \\
\hline T3(Biochar+bact)+O & $16.29 \mathrm{c}$ & $16.33 \mathrm{c}$ & $0.97^{\mathrm{a}}$ & $1.03^{\mathrm{a}}$ & $16.79 \mathrm{c}$ & $15.85 \mathrm{c}$ & $11.56 \mathrm{c}$ & $12.25 \mathrm{c}$ \\
\hline T4(Biochar+bact) & $16.22 \mathrm{~d}$ & $16.27 \mathrm{~d}$ & $0.94^{\mathrm{a}}$ & $1.00^{\mathrm{a}}$ & $17.25 \mathrm{~b}$ & $16.27 \mathrm{~b}$ & $8.87 \mathrm{~d}$ & $9.68 \mathrm{~d}$ \\
\hline T5(Rice husk nano)+O & $16.28 \mathrm{c}$ & $16.36 \mathrm{c}$ & $0.77^{\mathrm{c}}$ & $0.88^{\mathrm{c}}$ & $21.14 \mathrm{a}$ & $18.59 \mathrm{a}$ & $7.56 \mathrm{~d}$ & $10.12 \mathrm{~d}$ \\
\hline T6(Rice husk nano) & $16.20 \mathrm{~d}$ & $16.25 \mathrm{~d}$ & $0.73^{\mathrm{c}}$ & $0.85^{\mathrm{c}}$ & $22.19 \mathrm{a}$ & $19.11 \mathrm{a}$ & $7.87 \mathrm{~d}$ & $8.25 \mathrm{~d}$ \\
\hline T7(Ric husk nano+N)+O & $16.59 \mathrm{~b}$ & $16.68 \mathrm{~b}$ & $0.89^{\mathrm{b}}$ & $0.95^{\mathrm{b}}$ & $18.64 \mathrm{~b}$ & $17.55 \mathrm{~b}$ & $12.87 \mathrm{~b}$ & $13.37 \mathrm{c}$ \\
\hline T8(T2+T4+T7) & $16.67 \mathrm{a}$ & $17.2 \mathrm{a}$ & $0.99^{\mathrm{a}}$ & $1.09^{\mathrm{a}}$ & $16.83 \mathrm{c}$ & $15.77 \mathrm{c}$ & $14.87 \mathrm{a}$ & $16.62 \mathrm{a}$ \\
\hline
\end{tabular}

Means with the same letter in a column are not significantly different by DMRT 5\%

Same direction was found in total soluble solids (TSS), acidity and crude protein (Table 14) when T8 treatment employed resulted in significant augmentation in TSS 2.2 and 5\%, acidity 27 and $24 \%$ and crude protein 14 and $25 \%$ respectively over control T1 during both two seasons. Dissimilarity with those results was found in TSS/acidity ratio since T6 recorded the highest values significantly when compared to T8 and all other treatments and insignificant in comparison with control T1.

Similar results were found by Cooney et al., (2013) who mentioned that, biochar has positive impacts on different crops productivity, soil physical, chemical, and biological properties, Niaz et al., (2016) declared that, the yield of wheat crop significantly improved through appliance of biochar, and enhanced soil quality, increased organic carbon levels and improved soil water holding abilities, Soliman and Mahmoud, (2013) on Adansonia digitata L. represented that zeolite loaded with micronutrients mixed with organic fertilizer led to significant raise in vegetative growth, chemical composition as crude protein, plant pigments, total carbohydrates, ascorbic acid, N, P, K, Zn, Fe, Mn, B, Ca and Mg in comparison with the recommended commercial dose of chemical fertilizers NPK (control) under the same conditions.

Net photosynthesis, transpiration rate and water use efficiency:

Focusing on diurnal mean leaf photosynthesis rate of Vitis vinifera L. using different treatments as publicized in Fig. (6) divulged that, plants under mixture treatment represented in T8 donated the highest significant values 27 and $29 \%$ respectively for photosynthesis rate and 102 and $69 \%$ respectively for water use efficiency during both two seasons compared to 


\section{Macrothink}

Journal of Agricultural Studies

ISSN 2166-0379

2018, Vol. 6, No. 3

plants under control T1. Similar to mentioned results both T2 and T7 as well had the same effects since significant augmentations 24 and 27\% respectively were recorded with $\mathrm{T} 2$ and 26 and 23\% respectively with T7 in comparison with control T1. On the other side, the lowest values of transpiration rate were obtained from T8 judged against all other treatments in both first and second seasons.
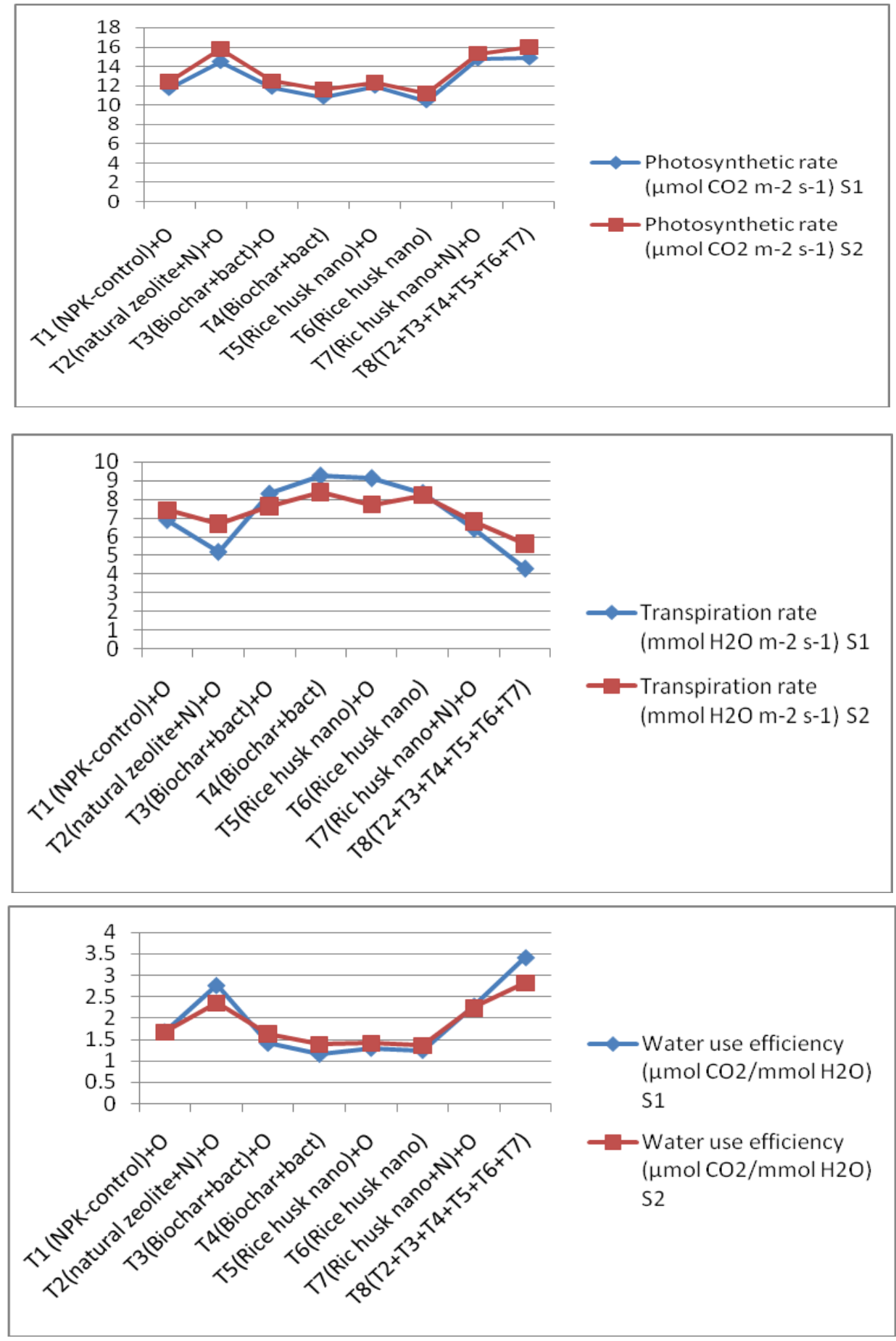

Fig.6. Effect of different treatments on net photosynthesis, transpiration and water use efficiency of Superior grapevine (Vitis vinifera L) leaves during two consecutive seasons $(\mathrm{S} 1=2016$ and $\mathrm{S} 2=2017)$. 


\section{Macrothink}

Journal of Agricultural Studies

ISSN 2166-0379

2018, Vol. 6, No. 3

Present results could be translated as there was affirmative relationship between photosynthetic rate and water use efficiency, while the decreased of photosynthetic rate in other treatments can be attributed to the direct inhibition of biochemical processes through ionic, osmotic or other conditions were induced by loss of cellular water. Some other factor that contributed to this diminish might be the limited $\mathrm{CO}_{2}$ diffusion into the intercellular spaces of the leaf as a consequence of reduced stomatal conductance (Lawlor, 2002). Consequently, application of combined treatment T8 produced significant increment in water use efficiency under desert condition and dripping water system. Commonly water use efficiency is a principally vital consideration whereas irrigation water resources are limited or diminishing and rainfall is a limiting factor as the condition of desert reclaimed areas. Furthermore one of the components of a management system that affects water use efficiency is soil fertility; therefore a complete fertility represented in combination of natural zeolite loaded nitrogen, biochar, biofertilizers, nano rice husk with and compost assist to produce plants with roots system that explore more soil volume for water and nutrients in less time. These outcomes represented in a healthier crop which can easily withstand seasonal stresses or conditions. (Stewart, 2001). Analogous with these results were reported by Soliman and Mahmoud, (2013) on Adansonia digitata and Mahmoud and Soliman, (2017) on evening primrose plant.

\section{Phytohormones}

As displayed in Fig. (7) endogenous plant hormones level represented in gibberellic acid $\left(\mathrm{GA}_{3}\right)$, indole-3-acetic acid (IAA) and abscisic acid (ABA) in grape leaves were significantly affected by different treatments where boosting in growth traits was linked with elevation of both hormones $\mathrm{GA}_{3}$ and IAA, consequently application of T8 treatment resulted in significant increase over all treatments particularly 44 and $43 \%$ for $\mathrm{GA}_{3}$ and 101 and $71 \%$ for IAA respectively compared to control treatment $\mathrm{T} 1$ during both growing seasons. 

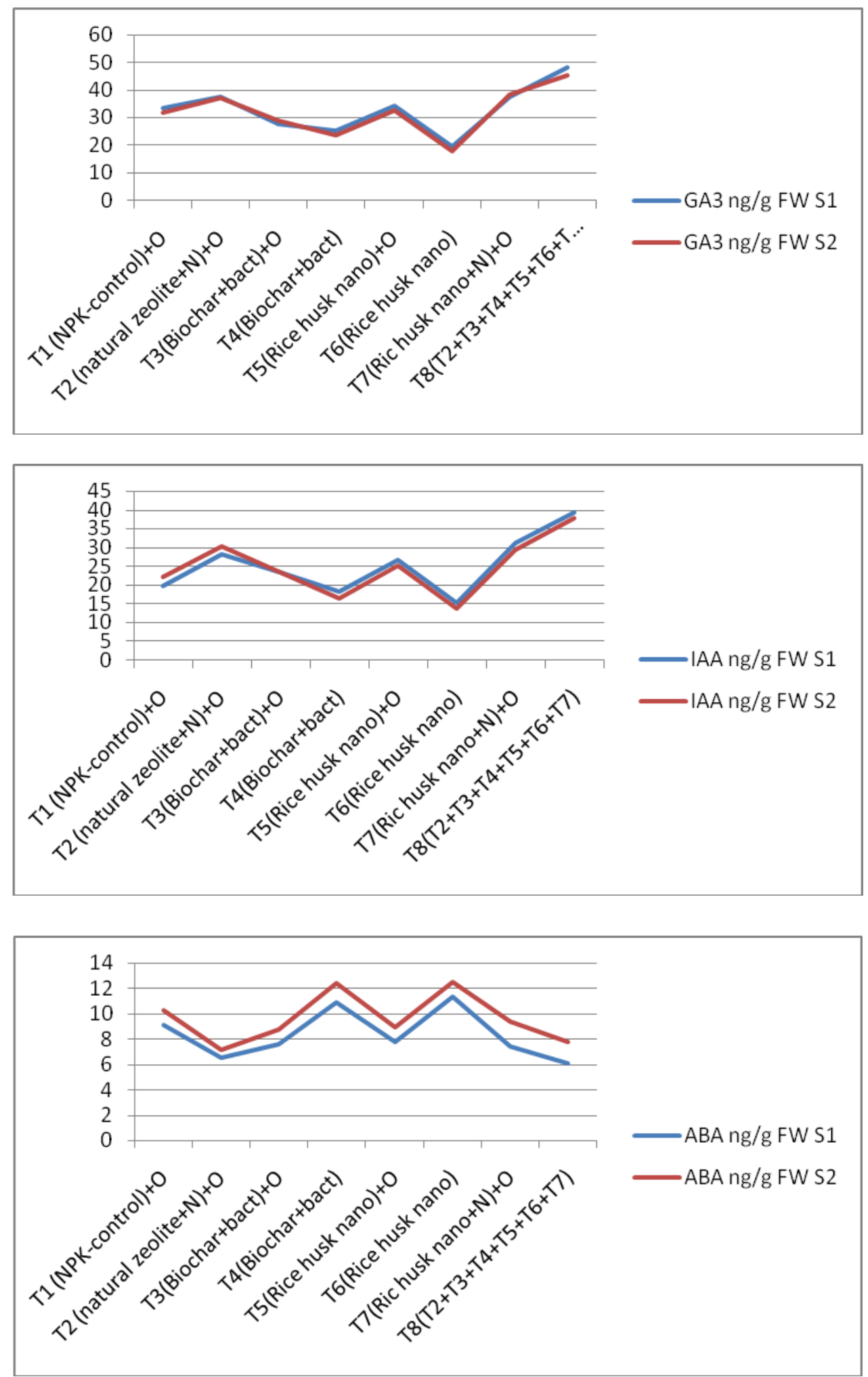

Fig 7. Effect of different treatments on gibberellic acid ( $\left.\mathrm{GA}_{3}\right)$, indole-3-acetic acid (IAA) and abscisic acid (ABA) of Superior grapevine (Vitis vinifera $\mathrm{L}$ ) leaves during two consecutive seasons $(\mathrm{S} 1=2016$ and $\mathrm{S} 2=2017)$ 


\section{Macrothink}

Focusing on other treatments, it was prominent that both $\mathrm{T} 2$ and $\mathrm{T} 7$ as well recorded significant augmentation over control (T1) with $\mathrm{GA}_{3}$ and IAA as well during both seasons. Whilst T4 and T6 gave the lowest amount of both mentioned two hormones for the period of both season. Pertaining to abscisic acid (ABA) hormone level in both seasons the highest amount significantly recorded with T6 treatment since donate 24 and $22 \%$ measure up to control treatment T1. Discrepancy with this found in $\mathrm{T} 8$ treatment which provided significantly the lowest amount of ABA contrasts to both T6 and T1 treatments.

The inspired consequences of mixture treatment (T8) may be refer to variety of sources inside starting by zeolite which has ability to maintain the majority of essential elements to provide plants in time of needs principally zinc ( $\mathrm{Zn}$ ) which boost tryptophan concentration which considered precursor of auxin (Taiz and Zeiger 2006). Also biofertilizers as mentioned by Marek and Skorupska, (2001) who provided evidence that, four different forms of GA are produced by various Bacillus sp. which efficiently provide a chemical-induced stem growth, together with organic matter, which is considered a source of macro and micronutrients and their power to stimulate plant growth and hormone-like substances.

The abovementioned results are in consonance with obtained by Soliman and Mahmoud, (2013) on Adansonia digitata L., Mahmoud and Soliman, (2017) on evening primrose plant and Mahmoud et al., (2017) on caraway plant.

Investment factor and economic evaluation:

The data in Table (15) obviously disclosed that, control plants represented in T1 realized a maximum production cost during both seasons [746 and 718 US dollar/h] respectively, away from this, combination treatment T8 recorded the lowest amount of production cost [125 and 112 US dollar/h] for both growing seasons, meanwhile the highest gross income [8352 and 8809 US dollar/h] as well as profitable return [8227 and 8696 US dollar/h] attained from T8 treatment application. Outstanding results were came into sight with both T4 and T6 treatments which donate negative amounts of profitable return (PR) and benefit cost ratio (BCR) that mean it were less than control treatment T1. 


\section{I Macrothink}

Table (15). Economic evaluation of different treatments

\begin{tabular}{|c|c|c|c|c|c|c|c|c|c|c|c|c|c|c|c|c|}
\hline \multirow[t]{2}{*}{ Treatments } & \multicolumn{2}{|c|}{$\begin{array}{l}\text { Total yield } \\
\text { Kg/h }\end{array}$} & \multicolumn{2}{|c|}{$\begin{array}{l}\text { Total production } \\
\text { cost } \\
\text { (US dollar/h.) }\end{array}$} & \multicolumn{2}{|c|}{$\begin{array}{l}\text { Gross income } \\
\text { (US dollar/h.) }\end{array}$} & \multicolumn{2}{|c|}{$\begin{array}{l}\text { Profitable return } \\
\qquad \text { (PR) } \\
\text { (US dollar/h.) }\end{array}$} & \multicolumn{2}{|c|}{$\begin{array}{c}\text { (PR) } \\
\text { over control } \\
\text { (US dollar/h.) }\end{array}$} & \multicolumn{2}{|c|}{$\begin{array}{c}\text { (PR\%) } \\
\text { increase } \\
\text { (US dollar/h.) }\end{array}$} & \multicolumn{2}{|c|}{ (BCR) } & \multicolumn{2}{|c|}{ (IF) } \\
\hline & 2016 & 2017 & 2016 & 2017 & 2016 & 2017 & 2016 & 2017 & 2016 & 2017 & 2016 & 2017 & 2016 & 2017 & 2016 & 2017 \\
\hline $\begin{array}{l}\text { T1(NPK as Control+ } \\
\text { O) }\end{array}$ & 13638 & 15771 & 746.875 & 718.75 & 6819 & 7885.5 & 6072.125 & 7166.75 & & & & & & & 9.13 & 10.97 \\
\hline $\begin{array}{l}\mathrm{T} 2 \text { (natural } \\
\text { zeolite+N)+O }\end{array}$ & 14266.6 & 16609 & 406.25 & 393.75 & 7133.3 & 8304.5 & 6727.05 & 7910.75 & 654.925 & 744 & 9.73 & 9.40 & 1.61 & 1.88. & 17.55 & 21.09 \\
\hline T4(Biochar+bact) & 9942.5 & 11752 & 680 & 40.625 & 4971.25 & 5876 & 4291.25 & 5835.375 & -1780.875 & -1331.375 & 41.50 & -22.81 & 2.61 & 32.77 & 7.31 & 144.64 \\
\hline $\begin{array}{l}\text { T5(Rice husk } \\
\text { nano)+O }\end{array}$ & 13390 & 15542 & 401.875 & 390.625 & 6695 & 7771 & 6293.125 & 7380.375 & 221 & 213.625 & 3.51 & 2.98 & 0.54 & 0.54 & 16.65 & 19.89 \\
\hline T6(Rice husk nano) & 7333 & 8190 & 52.5 & 46.875 & 3666.5 & 4095 & 4042.5 & 4048.125 & -2029.626 & -3118.625 & -50.20 & -77.03 & -38.65 & -66.53 & 69.83 & 87.36 \\
\hline $\begin{array}{ll}\text { T7(Rice } & \text { husk } \\
\text { nano+N)+O }\end{array}$ & 14190 & 16533 & 410 & 400 & 7095 & 8266.5 & 7856.5 & 7866.5 & 1784.375 & 699.75 & 22.71 & 8.89 & 4.35 & 1.74 & 17.30 & 20.66 \\
\hline $\mathrm{T} 8(\mathrm{~T} 2+\mathrm{T} 4+\mathrm{T} 7)$ & 16704 & 17619 & 125 & 112.5 & 8352 & 8809.5 & 8227 & 8696.5 & 2154.875 & 1529.75 & 26.19 & 17.59 & 17.23 & 13.59 & 66.81 & 78.30 \\
\hline
\end{tabular}

Based on dollar exchanging rate in 2016 and 2017

Concerning investment factor (IF) it was clearly that, the highest (IF) recorded with T4 especially in the second season, but commonly all treatments rewarded reasonable profitability since their (IF) more than 3. Moreover, T8 treatment donate the highest PR\% during both seasons [29.19 and 17.59] respectively and benefit cost ratio (BCR) as well since gave [17.23 and 13.59] respectively.

\section{Conclusion}

On the basis of preceding information, present investigation gave evidence that mixing between natural zeolite loaded nitrogen, biochar, biofertilizers (Bacillus megaterium and Azotobacter chroococcum), rice husk loaded nitrogen and compost in one treatment provided distinguished results on grape plant yield quantity (yield and market criteria) and quality (chemical constituents) besides improving soil properties (physical and chemical) and safety to our environment. Furthermore, economic costs evaluation which revealed the advantageous profitable return, low production cost and high gross income for farmers and producers. 


\section{Acknowledgments}

Present research was partially financially supported by the Cairo university-Faculty of Agriculture- Research park-Plant physiology department and Agriculture Research Center-Soil \&Water and Environmental Institute. The authors would like to thank all doctors and technical assistances at Labs for their valuable help and support.

\section{References}

Abdurahman Husien, Bobe Bedadi and Nigussie Dechassa (2017). Effect of Biochar, Farmyard Manure and Nitrogen Fertilizers on Soil Chemical Properties in Sinana, District, South Eastern Oromia, Ethiopia. International Journal of Applied Agricultural Sciences.3(6): 148-153.

Agaoglu Y.S. (2002).Vine Physiology. Kavaklıdere Eğitm Yayınları 5. 445 s., Ankara. (in Turkish).

Bevacqua, R. F. and Mellano, V. J. (1993). Sewage sludge compost, cumulative effects on crop growth and soil properties. Compost Sci. Util., 1 (13): 34-37.

Bevilacqua, A. E., and Califano, A. N. (1989). Determination of organic acids in dairy productsby high performance liquid chromatography. J. Fod Sci., 54(4), 1076-1076.

Cemeroglu, B., A. Yemenicioglu, and M. Ozkan (2004). Contents of Fruit and Vegetable. 1. Fruit and Vegetable Procesing Technology (Editor: B. Cemeroglu). 2. Başkent Klişe Matbacılk, 1.Ankara,, 670. (in Turkish).

Chan and Xu (2009). Biochar: Nutrient properties and their enhancement. In Biochar for environmental management: science and technology. Eds. J Lehmann and S Joseph. pp 67-84.

Cooney J.L., M.J., and Antal Jr (2013). Agronomic value of sewage sludge and corn cob biochar in an infertile Oxisol. Poster presented at 2013 Fall Meeting, American Geophysical Union, San Francisco, CA Dec. 9-13.

Dewis, J. and G. Freitas. (1970).Physical and chemical methods of soil and water analysis. Soils Bull. (10),P. 81, 78 FAO, Italy.

Dumas, Y.- Dadomo, M. - Dilucca, G. - Grolier, P. (2003). Effects of, environmental factors and agricultural techniques on antioxidant content of, tomatoes. In Journal of the Science of Food and Agriculture, vol. 83, no.5, pp.369-382.

Duncan, B.D., (1955). Multiple Range and Multiple F-Tests. Biometrics, 11: 1-42.

Fales, H.M. - Jaouni, T.M. - Babashak, J.F. (1973).Simple device for preparing ethereal diazomethane without resorting to codistillation. In Analytical Chemistry, vol. 45, no.13, pp. 2302-2303.

FAO. (2000). Fertilizers and their use. $4^{\text {th }}$ edition: handbook was prepared originally for use by extension officers working for the FAO Fertilizer Programme. Rome : FAO, p. 34. 
FAO. (2013). Food and Agriculture Organization of the United Nations.

http://www.fao.org/home/en/

FAO. (2015).The State of Food Insecurity in the World. report pp 62.

Galganoa, F., Favatia, F., Carusoa, M., Scarpaa, T. \& Palmab, A. (2008). Analysis of trace elements in southern Italian wines and their classification according to provenance. LWT, Food Sci. Technol. 41(10), 1808-1815.

Hassan AZA, Abdel Wahab M Mahmoud, G. Turky. (2017). Rice Husk Derived Nano Zeolite (A.M.2) as Fertilizer, Hydrophilic and Novel Organophillic Material. American Journal of Nanomaterials. 5(1), 11-23.

Hassan A. Z. A. and Abdel Wahab M Mahmoud (2015). Hydrothermal synthesis of nano crystals (A.M.), zeolite using variable temperature programs, Journal of Nanomaterials \& Molecular Nanotechnology Volume $4 \cdot$ Issue $4 \cdot 1000169$.

Hassan, A.Z.A. - Ghallab- Mahmoud, A.W.M. - Ghobashy, A.M. (2006). Response or rosemary plants to organic and inorganic biofertilizer in replacement of chemical fertilization. In Journal of Environmental Sciences, vol. 4, no. 2, pp.527-544.

Helrich, K. (1990). Official methods of analysis, 15th ed. Arlington, USA: Association of Official Agricultural Chemist. vol. 1, p. 673.

Huseyin, K.; Ahmet, E.; Metin, T. and Fikrettin, S. (2007). Effects of root inoculation of plant growth promoting rhizobacteria (PGPR) on yield, growth and nutrient element contents of leaves of apple. Scientia Horticulturae, 114: 16-20.

Jackson, M.L. (1973). Soil Chemical Analysis. New Delhi : Printice-Hall of India. Privat Limited, New Delhi. Text book. pp. 144-197, 381.

Jean-Baptiste, M. and M.Dupont. (1983). Zeolite-water close cycle solar refrigeration; numerical optimisation and field-testing, Proc. Annu. Meet. Am. Sect. Int. Sol. Energy Soc. ; Vol/Issue: 6 pp 181-185; American Solar Energy Society meeting; 1 June Minneapolis, MN, USA.

Jeffery, S.; Verheijen, F.G.A.; Van der velde, M.; Bastos, A.C. A (2011). quantitative review of the effects of biochar application to soils on crop productivity using meta-analysis. Agriculture, Ecosystems and Environment, v.144, p.175-187.

Junxi Li, Chido Wee , Bokyoon Sohn (2013). Effect of ammonium- and potassium-loaded zeolite on kale (Brassica alboglabra) growth and soil property. American Journal of Plant Sciences , 4, 1976-1982

Kallo, D.; Papp, J. and Terbe, I. (1986). Horticultural use of zeolite minerals. Kerteszeti-Egyetem-Kozlemenyei Publ. 50 (18): 47-56.

Klute, A. (1965). Laboratory measurement of hydraulic conductivity of saturated soil. In "Methods of Soil Analysis", Am. Soc. Agron. Inc. Publisher, Madison. Part I, pp 210-221. 
Lamikanra, O., Inyang, I., \& Leong, S. (1995). Distribution and effect of grape maturity on organic acid content of red Muscadine grapes. Journal of Agricultural and Food Chemistry, 43, 3026-3028.

Lawlor, D.W. (2002). Limitation to photosynthesis in water stressed leaves: stomata versus metabolism and the role of ATP. Annals of Botany. 89: 871-885.

Lehman RM, Cambardella CA and Stott DE. (2015). Understanding and enhancing soil biological health: The solution for reversing soil degradation. Sustainability,7: 988- 1027. Li, J. - Wee, C. - Sohn, B. (2013).Effect of ammonium-and potassium-loaded zeolite on kale, (Brassica alboglabra) growth and soil property. In American Journal of Plant Sciences, vol. 4, no.10, p.1976.

Mahmoud, A.W.M. - El-attar, A.B. - Mahmoud, A. A. (2017).Economic evaluation, of nano and organic fertilisers as an alternative source to chemical fertilisers on carum, carvi 1. plant yield and components. In Agriculture (Pol'nohospodárstvo), vol. 63, no.1, pp. 33-49.

Mahmoud, A.W.M. and Soliman, A. SH. (2017). Comparative study on the influence of organic fertilizer and soil amendments on evening primrose (Oenothera biennis L.). International Journal of Agricultural Research. Vol. 12 , No: 2. pp 52-63.

Mahmoud, A.W.M. (2012). Physiological effects of zeolite and organic fertilizers on yarrow plant grown under clean agriculture conditions. In PhD. Thesis, Plant Physiology Department, Fac. Agric., Cairo Univ., Egypt, pp.297.

Marek, K. and Skorupska, A. (2001). Production of B-group vitamins by plant growth promoting Pseudomonas fluorescens strain 267 and importance of vitamins in the colonization and nodulation of red clover. Biol. Fert. Soils, 33: 146-151.

Meda, A.- Lamien, C.E. - Romito, M.-Millogo, J. -Nacoulma,O.G.(2005).Determination of the total phenolic, flavonoid and proline contents in Burkina Fasan, honey, as well as their radical scavenging activity. In Food chemistry, vol. 91, no. 3, pp. 571-577.

Melgarejo, P., Salazar, D. M., and Artes, F. (2000). Organic acids and sugars composition of harvested pomegranate fruits. European Food Res. Tech., 21(3), 185-190.

McIntyre DS and Loveday J (1974). Particle size analysis. In 'Methods for analysis of irrigated, soils' Commonwealth Agricultural Bureaux Technical Bulletin No 54, p88-96.

Moran, R. (1982). Formulae for determination of chlorophyllous pigments extracted with N-dimethylformamide. In Plant physiology, vol .69, no. 6, pp. 1376-1381.

Mubashir, M.- Malik, S.A.- Khan, A.A.- Ansari, T.M.- Wright, S.- Brown,M.V.- Islam, K.R. (2010).Growth, yield and nitrate accumulation of irrigated carrot, and okra in response to nitrogen fertilization. In Pakistan Journal of Botany, vol. 42, no., 4, pp., 2513-2521.

Niaz Ahmad, Muhammad Imran, M.W. Riaz Marral, Muhammad Mubashir and Beenish Butt. (2016). Influence of Biochar on Soil Quality and Yield Related Attributes of Wheat (Triticum aestivum L.) Journal of Environmental and Agricultural Sciences, 7:68-72. 
Nikolas Hagemann, Stephen Joseph, Hans-Peter Schmidt, Claudia I. Kammann, Johannes Harter, Thomas Borch,Robert B. Young, Krisztina Varga, Sarasadat Taherymoosavi, K. Wade Elliott, Amy McKenna, Mihaela Albu, Claudia Mayrhofer, Martin Obst, Pellegrino Conte, Alba Dieguez-Alonso, Silvia Orsetti, Edisson Subdiaga, Sebastian Behrens \& Andreas Kappler. (2017). Organic coating on biochar explains its nutrient retention and stimulation of soil fertility. Nature Communications volume 8, Article number: 1089.

Noori, M. ; M. Zendehdel and A. Ahmadi. (2007). Using natural zeolite for the improvement of soil salinity and crop yield.Toxicological and environmental chemistry, 88(1):77-84.

Page A. I.; Miller, R. H. and Keeney, T. R. (1982). Methods of Soil Analysis part 2Amer. Soc. Agr. Inc. Madison WI9: pp 595.

Pirela, H.J. (1984). Agronomic and horticultural use of zeolites: a review. In: Pond WG, Mumpton FA (eds) Zeo-agriculture: use of natural zeolites in agriculture and aquaculture. West view Press, Boulder, CO, pp 93-103, 257-262.

Rapala-kozik, M.- Kowalska, E. - Ostrowska, K. (2008). Modulation of thiamine metabolism in Zea mays seedlings under conditions of abiotic stress. In Journal of experimental botany, vol. 59, no.15, pp. 4133-4143.

Reddy, K., Xie, T., Dastgheibi, S. (2014a). Evaluation of biochar as a potential filter media for the removal of mixed contaminants from urban storm water runoff. J.Environ. Eng., 04014043.

Reddy, K.R., Yargicoglu, E.N., Yue, D., Yaghoubi, P. (2014b).Enhanced microbial methane oxidation in landfill cover soil amended with biochar. J. Geotech. Geoenviron. Eng., ASCE 140 (9), 04014047.

Robertson, S. J., Rutherford, M. P., López-Gutiérrez, J. C., and Massicotte, H. B. (2012). Biochar enhances seedling growth and alters root symbioses and properties of sub-boreal forest, soils, Can. J.Soil Sci., 92, 329-340.

Sarwar, G.- Hussain, N.- Schmeisky, H.- Muhammad, S.- Ibrahim, M. -Safdar, E. (2007).Use of compost an environment friendly technology for enhancing, rice-wheat production in Pakistan. In Pakistan Journal of Botany, vol. 39, no. 5, pp.1553-1558.

Shackley, S.; Sohi, S.P. (2010). An Assessment of the Benefits and Issues Associated with the Application of Biochar to Soil; Report to the Department for Environment, Food and, Rural Affairs and the Department of Energy and Climate Change: London, UK, pp. 14- 132.

Singleton, V.L. -Rossi, J.A. (1965). Colorimetry of total phenolics with phosphomolybdic-phosphotungstic acid reagents. In American journal of Enology and Viticulture, vol. 16, no. 3, pp.144-158,

Soliman, A. SH. - Mahmoud, A.W.M. (2013). Response of adansonia digitata to, compost and zeolite in replacement of chemical fertilization. In American-Eurasian Journal of Agricultural \& Environmental Sciences, vol. 13, no. 2, pp. 198-206.

Sousa, C.- Pereira, D. M. - Pereira, J.A. - Bento, A. -Rodrigues, M.A.- Garcia, D.S. - 


\section{Macrothink}

Valentao, Lopes, P. - Ferreres, G. - Seabra, F.-Andrade, P.B. (2008). Multivariate analysis of tronchuda cabbage (Brassica oleracea, L. var. costata DC) phenolics: influence of fertilizers. In Journal of Agricultural and Food Chemistry, vol.56, no.6, pp. 2231-2239.

Taiz, L. and E. Zeiger. (2006). Plant Physiology, $4^{\text {th }}$ ed., Sinauer Associates, Inc., Publishers, Sunderlands, Massachusetts, p. 764.

Tisdale, S.L. - Nelson, W.L. (1975).Soil Fertility and Fertilizers, In 3rd Edition. Macmillan Publishing, New York, USA. pp 694,

Vogel, A.I. (1975). A text book of practical organic chemistry. Published by English Language Book society and Longman Group Limited $3^{\text {rd }}$ Ed., pp. 197-596.

White, A.C.- Rogers, A.- Rees, M.- Osborne, C.P. (2016). How can we make plants, grow faster? A source-sink perspective on growth rate. In Journal of Experimental, Botany, vol.67, no. 1 , pp. 31-45.

Yasuda, H., K. Takuma, N. Mizuta, and H. Nishide. (1995). Water retention variety of dune sand due to zeolite addition. Bulletin Faculty of Agriculture [Japan: Tottori University] 48:27-34.

\section{Copyright Disclaimer}

Copyright for this article is retained by the author(s), with first publication rights granted to the journal.

This is an open-access article distributed under the terms and conditions of the Creative Commons Attribution license (http://creativecommons.org/licenses/by/4.0/). 